\title{
Sovereign Immunity, Due Process, and the
}

\section{Alden Trilogy}

\section{Carlos Manuel Vázquez ${ }^{\dagger}$}

On the last day of the Supreme Court's 1998 Term, the Justices delivered their opinions in Alden v. Maine ${ }^{l}$ from the bench with great drama, reportedly holding spectators spellbound for close to an hour. ${ }^{2}$ The Court's holding in that case that the doctrine of sovereign immunity protects states from being sued in their own courts without their consent even on federal claims has been the subject of much commentary, most of it unfavorable. ${ }^{3}$ What has received less attention is that, in another decision handed down the same day, Florida Prepaid Postsecondary

$\div$ Professor of Law, Georgetown University Law Center. I am grateful to Brian Bix, Michacl Carroll, Julie Cohen, John Echeverria, Vicki Jackson, William Kelley, Richard Parker, Wendy Collins Purdue, Jay Tidmarsh, and Mark Tushnet-and the participants in the Notre Dame Law School Faculty Colloquium and Georgetown Faculty Workshop-for their comments. I am also indebted to Peter Klason for outstanding research assistance.

1. 119 S. Ct. 2240 (1999).

2. See Linda Greenhouse, States Are Given New Legal Shield by Supreme Coun. N.Y. TIMES, June 24, 1999, at A1.

3. See, e.g., Ann Althouse, The Alden Trilogy: Still Searching for a Way To Enforce Federalism, 31 RUTGERS L.J. (forthcoming Apr. 2000); Daniel A. Farber. Pledging a New Allegiance: An Essay on Sovereignty and the New Federalism, 75 NotRE DAME L. REV. (forthcoming Mar. 2000); William A. Fletcher, The Eleventh Amendment: Unfinished Business, 75 NOTRE DAME L. REV. (forthcoming Mar. 2000): Vicki C. Jackson. Principle and Compromise in Constitutional Adjudicarion: The Eleventh Amendment and State Sovereign Immuniny. 75 NOTRE DAME L. REV. (forthcoming Mar. 2000) [hereinafter Jackson. Principle and Compromise]; Vicki C. Jackson, Seductions of Colterence. State Sovereign Immunity and the Denationalization of Federal Law, 31 RUTGERS L.J. (forthcoming Apr. 2000); William P. Marshall \& Jason S. Cowart, State Immunity, Political Accountability, and Alden v. Maine, 75 NOTRE DAME L. REV. (forthcoming Mar. 2000); Danicl J. Meluer, State Sovereign Immunity: Five Authors in Search of a Theory, 75 NOTRE DAME L. REV. (forthcoming Mar. 2000): John E. Nowak, The Gang of Five and the Second Coming of an Anti-Reconstruction Supreme Court, 75 NOTRE DAME L. REV. (forthcoming Mar. 2000); John V. Orth. Histon and the Eleventh Amendment, 75 NOTRE DAME L. REV. (forthcoming Mar. 2000); James E. Pfander, Once More unto the Breach: Eleventh Amendment Scholarship and the Cour, 75 NOTRE DAME L. REV. (forthcoming Mar. 2000); Suzanna Sherry, Stares Are People Too. 75 NOTRE DAME L. REV. (forthcoming Mar. 2000); Jay Tidmarsh, A Dialogic Defense of Alden, 75 NOTRE DANE L. REV. (forthcoming Mar. 2000); Carlos Manuel Vázquez, Eleventh Amendment Schizophrenia, 75 NOTRE DAME L. REV. (forthcoming Mar. 2000); Michael Wells. Suing Stares for Money: Constitutional Remedies After Alden and Florida Prepaid, 31 RuTGERS L.J. (forthcoming Apr. 2000); Ann Woolhandler, Old Property. New Property; and Sovereign Imumunity. 75 NOTRE DAME L. REV. (forthcoming Mar. 2000). 
Education Expense Board v. College Savings Bank, ${ }^{4}$ the Court reaffirmed a competing principle that may contain the seeds of Alden's substantial undoing. The Court in Florida Prepaid held that the states' sovereign immunity is subject to the Due Process Clause, which requires a state to provide a remedy to individuals when it willfully deprives them of liberty or property in violation of federal law. When property or liberty is at stake, in other words, the rule appears to be the opposite of what the Court held in Alden: The state is required to provide individuals a remedy in its own courts.

How far the due process principle undoes the sovereign immunity principle depends in large part on how the Court defines "liberty" and "property." A third decision handed down that day, College Savings Bank v. Florida Prepaid Postsecondary Education Expense Board, makes it clear that the concept of "property" is not so capacious as to undo Alden's sovereign immunity principle entirely. College Savings Bank holds that not all violations of federal statutes that entitle individuals to damages deprive individuals of property. But earlier precedent that the Court did not mention or purport to disturb indicates that "liberty" and "property," though not "infinite," 6 are "broad and majestic" in scope. "In a Constitution for a free people," the Court has said, "there can be no doubt that the meaning of 'liberty' must be broad indeed." ${ }^{8}$ And " $[t]$ he Court has also made clear that the property interests protected by procedural due process extend well beyond actual ownership of real estate, chattels, or money."9 Indeed, under these precedents, the due process principle appears to be broad enough to have required the opposite result in Alden itself, had the principle been invoked in that case. In other words, Florida Prepaid, in conjunction with extant precedent regarding the meaning of "property," suggests that the Due Process Clause required Maine to afford Alden the remedy that the Court in Alden held Maine would otherwise have been entitled to deny on sovereign immunity grounds.

The claim that the principle reaffirmed in Florida Prepaid substantially undoes the principle articulated in Alden is of course in tension with the widespread belief that Alden was an important decision. The Alden majority itself at one point sought to downplay the practical significance of its

4. 119 S. Ct. 2199 (1999) [hereinafter referred to in the text as Florida Prepaid].

5. 119 S. Ct. 2219 (1999) [hereinafter referred to in the text as College Savings Bank]. College Savings Bank and Florida Prepaid originated as a single case, but the patent claims involved in Florida Prepaid were appealed to the Federal Circuit, while the claims involved in College Savings Bank were appealed to the Third Circuit. See Florida Prepaid, 119 S. Ct. at 2203 n.1.

6. Board of Regents v. Roth, 408 U.S. 564,570 (1972).

7. Id. at 571 .

8. Id. at 572 .

9. Id. at $571-72$. 
holding by pointing to mechanisms left open for enforcing the federal legal obligations of the states-mechanisms such as suits against the states by the federal government, ${ }^{10}$ private suits seeking prospective relief, ${ }^{11}$ and private suits seeking damages from state officials in their individual capacities.' These mechanisms, not to mention Congress's power to procure state waivers of immunity through its spending power, diminish the practical importance of Alden's holding that private damages actions against the states are unavailable in state as well as federal courts. But the majority's stated reasons for unconcern did not include the Due Process Clause's guarantee of a remedy against the states in certain cases. The claim that Florida Prepaid largely undoes Alden is also inconsistent with the apocalyptic nature of the remarks of the dissenting Justices, both in their opinions and from the bench. This Essay suggests that, if Alden is significant, its significance may lie in the changes that it portends for due process doctrine. If, under current understandings of "liberty" and "property," the due process principle largely undoes the sovereign immunity principle, Alden's strong articulation of the sovereign immunity principle may reflect a repudiation of those understandings.

It is possible that the Court's decision in Alden reflects neither its conscious articulation of an insignificant sovereign immunity principle nor its intention to repudiate due process doctrine that would otherwise render its holding insignificant. A third possibility is that the Court decided these cases without fully working through the implications of its decision for collateral doctrine, even doctrine implicated in decisions handed down the same day. ${ }^{13}$ If that is what happened, this failure to work through the

10. See Alden v. Maine, 119 S. Ct. 2240, 2267 (1999). The Eleventh Amendment does not protect the states from suits in federal court brought by the federal govemment. See Principality of Monaco v. Mississippi, 292 U.S. 313, 328-29 (1934).

11. See Alden, 119 S. Ct. at 2267; Ex parte Young, 209 U.S. 123 (1908). On the distinction between prospective and retrospective relief, see generally Carlos Manuel Vizquez, Night and Day: Coeur d'Alene, Breard, and the Unraveling of the Prospective-Rerrospective Distinction in Eleventh Amendment Doctrine, 87 GEO. L.J. 1 (1998).

12. See Alden, 119 S. Ct. at 2267-68; Scheuer v. Rhodes, 416 U.S. 232 (1974).

13. That the Court did not think through its analysis of "property" in College Savings Bank with its usual rigor is suggested by the fact that much of this portion of its opinion appears to have been lifted from the Solicitor General's brief in the case, which "conceded" that the bank had not been deprived of a property interest. Compare College Sav. Bank v. Florida Prepaid Postsecondary Educ. Expense Bd., 119 S. Ct. 2219, 2224 (1999) (stating that the "hallmark" of a property interest is the right to exclude others), and id. (stating that trademarks are property because others may be excluded from infringing them), and id. at 2225 (finding that the "misrepresentations concerning its own products intruded upon no interest over which petitioner had exclusive dominion"), with Brief for the United States as Petitioner. College Sav. Bank (No. 98-149), available in 1999 WL 95503, at *31-32 (describing property as a bundle of rights with the most important being the right to exclude), and id. at $* 32$ (stating that trademarks and other intellectual property are property because they include the right to exclude), and id. (stating that "misrepresentations conceming its own products effected no intrusion upon any tangible or intangible interest over which [College Savings Bank] possesses exclusive dominion"). If the decision in College Savings Bank does in fact signal the demise of the Court's "new property" 
ramifications of one case for another may have been caused in part by the fact that (1) the three cases were briefed and argued separately by different lawyers, (2) each of the opinions in the trilogy was assigned to a different Justice, and (3) perhaps most importantly, the litigants in Alden failed to invoke the due process principle.

Part I of this Essay examines what Alden tells us about the nature of state sovereign immunity. I conclude that the Court rejected the "forumallocation" interpretation of the Eleventh Amendment, and implicitly adopted what I have called the "immunity-from-liability" interpretation, under which the states are immune from being subjected to damage liability to individuals. ${ }^{14}$ College Savings Bank confirms that this is how the Court now understands state sovereign immunity. Part II discusses the nature of the due process principle reaffirmed in Florida Prepaid. I conclude that, although the due process regime contemplated in Florida Prepaid for remedying violations of liberty and property may differ from the forumallocation regime in nontrivial ways, it is fair to characterize Florida Prepaid as a partial resurrection of the forum-allocation regime. Finally, I consider in Part III the extent to which last Term's decisions, primarily College Savings Bank, retreat from the broad definition of property that the Court had articulated in earlier cases. The Court's approach to property in College Savings Bank clearly reflects a change from its approach in past cases, but just how far the Court has retreated remains unclear, primarily because the reasons the Court gave for its conclusion that the College Savings Bank plaintiff was not suing to enforce a property interest were unpersuasive and internally inconsistent.

If last Term's decisions do signal a dramatic narrowing of the scope of the property and liberty protected by the Due Process Clause, they show that the sovereign immunity tail is beginning to wag a very large due process dog. To accommodate its holdings denying individuals certain remedies against states, the Court may have substantially narrowed concepts that trigger very basic procedural rights. If these decisions do not reflect a conscious decision to move due process doctrine in this direction. the decisions' principal legacy may be a far more complex, and far less coherent, sovereign immunity and due process doctrine. Although

\footnotetext{
jurisprudence, it is ironic that the death knell has been sounded in a case in which the government "conceded" the point, as the point was also conceded in the case most closely associated with "new" property, Goldberg v. Kelly, 397 U.S. 254 (1970). See infra note 171 and accompanying text. (I have placed quotation marks around the term "conceded" because. while the government's position in Goldberg was a genuine concession, its position in College Savings Bank was not necessarily one. The federal government had an interest in having the Lanham Act upheld, but it also had an interest in narrowing the circumstances in which it would be required to provide due process.)

14. See Carlos Manuel Vázquez, What Is Eleventh Amendment Immunity?, 106 Yale L.J. 1683 , 1700-08 (1997) (describing the "forum-allocation" and "immunity-from-liability" interpretations).
} 
sovereign immunity doctrine has often been criticized as inconsistent with rule-of-law aspirations because it leaves some rights without corresponding remedies, the Court's latest decisions suggest that this doctrine's most problematic feature from a rule-of-law perspective may be its bewildering complexity.

\section{ALDEN AND THE ADOPTION OF THE IMMUNITY-FROM-LIABILITY VIEW}

In Hans v. Louisiana, ${ }^{15}$ the Court held that the Eleventh Amendment protects states from being sued in federal court even for violations of federal obligations. The holding has been controversial because of the ruleof-law problem it appears to create. ${ }^{16}$ The Eleventh Amendment, so interpreted, appears to violate two related requirements of the rule-of-law ideal: that there be a legal remedy for the violation of a legal right, ${ }^{17}$ and that the judicial power be coextensive with the legislative. ${ }^{18}$ The Constitution imposes numerous legal obligations on the states and gives Congress the power to impose additional ones, but the Eleventh Amendment, as interpreted in Hans, protects the states from being sued by private parties in the federal courts for violating such obligations. Scholars and dissenting Justices have argued that the Eleventh Amendment, properly construed, limits Article III's diversity grants of jurisdiction insofar as they confer jurisdiction in certain suits against states, but does not limit the grant of federal-question jurisdiction, ${ }^{19}$ and that Hans was accordingly wrongly decided. If so interpreted, the Eleventh Amendment would be unproblematic from a rule-of-law perspective. The Court came close to overruling Hans in Welch v. Texas Department of Highways \& Public Transportation, ${ }^{20}$ and in Pennsylvania v. Union Gas ${ }^{21}$ it arguably did

15. 134 U.S. 1,15 (1890).

16. See Vázquez, supra note 14, at 1686.

17. See Marbury v. Madison, 5 U.S. (1 Cranch) 137, 163 (1803).

18. See Osbom v. Bank of the United States, 22 U.S. (9 Wheat.) 738. 818-19 (1824): THE FEDERALIST No. 81, at 451-52 (Alexander Hamilton) (Clinton Rossiter ed., 1999).

19. This is the so-called diversity interpretation of the Eleventh Amendment. See Welch v. Texas Dep't of Highways \& Pub. Transp., 483 U.S. 468, 497-98 (1987) (Brennan. J., dissenting): Atascadero State Hosp. v. Scanlon, 473 U.S. 234, 301 (1985) (Brennan, J., dissenting): Akhil Reed Amar, Marbury, Section 13, and the Original Jurisdiction of the Supreme Court. 56 U. CHI. L. REV. 443, 494-95 (1989); Akhil Reed Amar, Of Sovereignty and Federalism, 96 YALE L.J. 1425, 1475-84 (1987); William A. Fletcher, A Historical Interpresation of the Eleventh Amendment: A Narrow Construction of an Affirmative Grant of Jurisdiction Rather than a Prohibition Against Jurisdiction, 35 STAN. L. REV. 1033 (1983); John J. Gibbons, The Eleventh Amendment and State Sovereign Immunity: A Reinterpretation, 83 COLUM. L. REV. 1889. 2004 (1983); Vicki C. Jackson, The Supreme Court, the Eleventh Amendmens, and State Sovereign Immunity, 98 YALE L.J. 1, 4 (1988); James E. Pfander, History and State Suabilin: An "Explanatory" Account of the Eleventh Amendment, 83 CORNELL L. REV. 1269. 1273 (1998).

20. 483 U.S. 468 (1987). The Cour, with Justice Scalia reserving judgment, was evenly divided on whether to embrace the diversity interpretation.

21. 491 U.S. 1 (1989) (Brennan, J., plurality opinion). 
overrule Hans, for all practical purposes, ${ }^{22}$ when it held that Congress has the power to abrogate Eleventh Amendment immunity pursuant to Article I. But the Court emphatically reaffirmed Hans three Terms ago when it overruled Union Gas in Seminole Tribe v. Florida. ${ }^{23}$ According to the majority in Seminole Tribe, Congress has the power to abrogate Eleventh Amendment immunity pursuant to Section 5 of the Fourteenth Amendment, but not pursuant to "antecedent provisions of the Constitution." 24

Until the past Term, a different line of cases promised a different, but nearly as satisfying, escape from the rule-of-law problems posed by Hans. Relying on Cohens $v$. Virginia ${ }^{25}$ in which the Supreme Court held that the Eleventh Amendment does not limit the Supreme Court's appellate jurisdiction over cases against states litigated in the state courts, even if the state did not consent to federal review, scholars had read the Court's Eleventh Amendment cases as establishing that the amendment grants merely an immunity from the original jurisdiction of the federal courts. ${ }^{26}$ On this view, which had become known as the "forum-allocation" view, neither the Eleventh Amendment nor any other principle of state sovereign immunity having constitutional stature has any bearing on the remedies to which states are subject if they violate federal law. The Eleventh Amendment protects states from suits in federal court by private parties seeking certain types of remedies, but that just means that persons aggrieved by state violations of federal law must seek those remedies in state courts. Under the Supremacy Clause, the state courts must entertain suits seeking such remedies, and if they fail to afford the remedy required by federal law (a matter unaffected by sovereign immunity under this theory), the U.S. Supreme Court may reverse their judgments.

22. In an apparent attempt to garner Justice White's vote, Justice Brennan's plurality opinion did not rely on the diversity theory. Instead, in reliance on Parden v. Terminal Railway, 377 U.S. 184 (1964), the plurality concluded that the states consented to congressional abrogation of their sovereign immunity under Article I when they joined the Union. See Union Gas, 491 U.S. at 1415 (Brennan, J., plurality opinion). For an explanation of how this holding gutted Hans, see id. at 35-42 (Scalia, J., concurring in part and dissenting in part); and Vazquez, supra note 14, at 169899. Justice White voted with the plurality, but he did not join the plurality opinion. Instead, he wrote cryptically that, while he agreed with the plurality's conclusion, he did not agree with all of its reasoning. See Union Gas, 491 U.S. at 45 (White, J., concurring in part and dissenting in part). In later overruling Union Gas, the Court relied in part on the absence of a stated rationale that the majority of the Court agreed upon. See Seminole Tribe v. Florida, 517 U.S. 44, 63 (1996).

23. 517 U.S. 44.

24. Id. at 66 (quoting Union Gas, 491 U.S. at 42 (Scalia, J., concurring in part and dissenting in part)).

25. 19 U.S. (6 Wheat.) 264,392 (1821).

26. See Jackson, supra note 19, at 15. According to Professor Jackson, even the forumallocation interpretation is too broad. See id. at 74. In her view, the Eleventh Amendment's forumallocation function should be understood as a rule of federal common law, alterable by the Congress. See id. at 74-75. 
The Supreme Court appeared to embrace this theory in three cases. In McKesson Corp. v. Division of Alcoholic Beverages \& Tobacco, ${ }^{77}$ the Court unanimously reaffirmed the holding of Cohens that the Eleventh Amendment does not limit the Supreme Court's appellate jurisdiction over suits brought against the states in state courts, even if the state does not consent to Supreme Court review. The Court in McKesson held in addition that the Due Process Clause sometimes requires the states to afford remedies in their own courts that the Eleventh Amendment would preclude the federal courts from awarding, ${ }^{28}$ and in Reich $v$. Collins, ${ }^{29}$ the Court, unanimously again, made it clear that when the Due Process Clause requires the remedy, the Supremacy Clause vitiates any claim of sovereign immunity in the state courts. Finally, in Hilton v. South Carolina Public Railways Commission, ${ }^{30}$ a majority of the Court affirmed that the Federal Employers' Liability Act (FELA) ${ }^{31}$ subjects states to monetary liability even though the Eleventh Amendment protects states from private damage suits in federal court under that statute. The Court said that "the Eleventh Amendment does not apply in state courts," ${ }^{32}$ and that when "a federal statute does impose liability upon the States, the Supremacy Clause makes that statute the law in every State, fully enforceable in state court." 33

In Alden, however, the Court directly addressed the forum-allocation view and definitively rejected it. ${ }^{34}$ The plaintiffs, employees of the State of Maine, claimed that the state had violated their federally guaranteed right to a minimum wage. ${ }^{35}$ Congress had made it clear in amendments to the Fair Labor Standards Act that states not only were required to pay the minimum wage, but also could be sued by employees in federal and state courts for alleged violations. ${ }^{36}$ The plaintiffs had brought suit in federal court before the Court decided in Seminole Tribe that Congress lacked the power to abrogate Eleventh Amendment immunity pursuant to its Article I powers. Soon after the Seminole Tribe decision, the district court dismissed the lawsuit, concluding that Congress had enacted the FLSA under its Commerce Clause Power, ${ }^{37}$ and the court of appeals

27. 496 U.S. 18, 26-27 (1990). This holding was reaffirmed unanimously last Term in South Central Bell Telephone Co. v. Alabama, 119 S. CL 1180 (1999).

28. See McKesson, 496 U.S. at 31.

29. 513 U.S. 106, 109-13 (1994).

30. 502 U.S. 197,207 (1991).

31. 45 U.S.C. $\$ \S 51-60$ (1994).

32. Hilton, 502 U.S. at 205 (quoting Will v. Michigan Dep't of State Police, 491 U.S. 58, 6364 (1989)).

33. Id at 207.

34. See Alden v. Maine, 119 S. CL. 2240, 2260-62 (1999).

35. See id at 2246.

36. See Fair Labor Standards Amendments of 1974. Pub. L. No. 93-259. 88 Stat. 55 (codified as amended in scattered sections of 29 U.S.C.).

37. See Mills v. Maine, No. 92-410-P-H. 1996 U.S. Dist. LEXIS 9985, at 7 (D. Me. July 3. 1996). 
affirmed..$^{38}$ The employees then brought the same suit in state court, arguing that the Eleventh Amendment protected the state only from being sued in federal court, and that the Supremacy Clause required the state to entertain the congressionally created cause of action and to afford the congressionally created remedy of backpay, notwithstanding the sovereign immunity it would otherwise enjoy. ${ }^{39}$ The state moved to dismiss the suit on the ground that, under Maine law, the state is immune from this sort of action. ${ }^{40}$ The Maine trial court dismissed the lawsuit on sovereign immunity grounds, ${ }^{41}$ and a divided Maine Supreme Judicial Court affirmed. ${ }^{42}$

The U.S. Supreme Court affirmed, with the same four Justices dissenting as in Seminole Tribe. ${ }^{43}$ Contrary to some of the commentary immediately following the decision, ${ }^{44}$ Alden does not call into question the validity of primary obligations imposed by Congress on states. The Court noted, and even relied on, its prior holding that the FLSA is "binding" on the states even though states remain immune from "private suit to recover under that Act." 45 The fact that the states enjoy sovereign immunity, the Court stressed, "does not confer upon [them] a concomitant right to disregard the Constitution or valid federal law." 46 Indeed, one of the Court's principal points was that the existence of a valid "substantive federal law" - by which the Court evidently meant a law that validly imposes primary obligations on the states - does not vitiate a claim of sovereign immunity. ${ }^{47}$ " [T] $]$ he question is not the primacy of federal law but the implementation of the law in a manner consistent with the constitutional sovereignty of the States." 48 Thus, the states remain obligated to pay the

38. See Mills v. Maine, 118 F.3d 37, 55 (1st Cir. 1997).

39. See Alden, 119 S. Ct. at 2246.

40. See id.

41. See id.

42. See Alden v. State, 1998 Me. 200 , II 11 . A majority of four justices agreed that the state was protected by its sovereign immunity, see id. 1 , while two dissenters would have held that the FLSA preempted any claim of sovereign immunity by virtue of the Supremacy Clause, see id. \14.

43. Compare Alden, 119 S. Ct. at 2269 (dissenting opinions), with Seminole Tribe v. Florida, 517 U.S. 44, 76, 100 (1996) (dissenting opinions).

44. See, e.g., Erwin Chemerinsky, Permission To Litigate: Sovereign Immunity Lets Stutes Decide Who Can Sue Them, A.B.A. J., Aug. 1999, at 42; The Supreme Court: Activism in Different Robes, ECONOMIST, July 3, 1999, at 22.

45. Alden, 119 S. Ct. at 2255 (citing Employees of Dep't of Pub. Health \& Welfare v. Department of Pub. Health \& Welfare, 411 U.S. 279, 283 (1973)).

46. Id. at 2266 .

47. Id. at 2255 .

48. Id. at 2255-56. 
minimum wage. ${ }^{49}$ Sovereign immunity merely bars certain (but not all) means of enforcing this obligation. ${ }^{50}$

If the states' sovereign immunity is fully compatible with congressional imposition of primary obligations on states, from what exactly does this immunity protect states? Under the forum-allocation view, sovereign immunity protects states only from the original jurisdiction of the federal courts. Congress retains the power to impose primary obligations on states and to subject them to private damage liability to individuals injured by violations. State courts are in turn obligated by the Supremacy Clause to entertain such actions. The Court in Alden clearly rejected that theory. Although it is less clear from the Alden opinion that it adopted what I have called the immunity-from-liability view, the opinion is susceptible to such an interpretation, and College Savings Bank confirms that the Court now adheres to the immunity-from-liability view. ${ }^{\text {s1 }}$

Under the immunity-from-liability view, Congress lacks the power to subject states to damage liability to individuals for violations of federal statutes. The federal obligations of the states may still be enforced prospectively in private suits against individual officers, and state officers may be liable to individuals for damages in their individual capacities, ${ }^{52}$ but the states themselves may not be subjected to such liability. The majority in Alden never declared that the states were free from liability to individuals. Instead, it purported to hold only "that the States retain immunity from private suit in their own courts." ${ }^{53}$ At a number of points in the majority opinion, the Court described another possible immunity of states-a broader immunity from "Congress' power to subject States to private suits" regardless of the forum..$^{54}$ Although in the end, it did not expressly adopt the latter interpretation of state sovereign immunity, some of the support it cited for its holding would support this broader interpretation as well. ${ }^{35}$ But

49. The Constitution does limit the federal govemment's power to impose obligations on the states, see Printz v. United States, 521 U.S. 898, 933 (1997); New York v. United States, 505 U.S. 144,162 (1992), but the sovereign immunity cases do not concern this son of limit.

50. See infra text accompanying note 80. In this respect, the Court's more recent decision in Kimel v. Board of Regents, $120 \mathrm{~S}$. Ct. 631 (2000), offers a striking contrast. As has become customary, the Court noted at the end of its opinion that its holding does not leave persons in the plaintiffs' position entirely without a remedy. See id. at 650 . See generally Vázqucz, supra note 3 (giving examples of similar statements in past decisions). But, rather than emphasize that the federal obligations imposed by the Age Discrimination in Employment Act (ADEA), 29 U.S.C.A. $\$ \S 621-634$ (West Supp. 1999), remained binding on states and enforceable against them in suits by the federal government or in private suits against state officials for prospective relief. the Court in Kimel merely noted that state laws protect state employces against age discrimination. See Kimel, 120 S. Ct. at 650.

51. See infra text accompanying notes 82-93.

52. On these alternative mechanisms for enforcing the federal obligations of the states, see generally Vázquez, supra note 3.

53. Alden, 119 S. Ct. at 2266 (emphasis added).

54. Id at 2259.

55. See infra notes $65-68$ and accompanying text. 
even in this broader articulation, the Court described the immunity as an immunity from "suits," not an immunity from liability as such.

Is the Court's holding nevertheless necessarily a holding that states are immune from congressionally imposed liability to individuals? In the light of its earlier holding that states are immune from private damage suits in federal court for violation of statutes enacted under Article I, is its holding in Alden that states are also entitled to immunity from such suits in their own courts tantamount to a holding that states are immune from private damage liability? There appear to be two possible ways to escape this conclusion. First, the Court did not expressly overrule its holding in Nevada v. Hall ${ }^{56}$ that states do not enjoy any constitutional immunity from suits in the courts of sister states. In the light of Hall, the narrow holding that states are immune from congressionally imposed private suits in their own courts would in theory be consistent with the existence of a federal liability that could be enforced against the states without their consent in the courts of sister states. ${ }^{57}$ This possibility would appear to be excluded by the broader view-not expressly embraced in Alden-that the states' immunity is an immunity from being subjected by Congress to private damage suits "in any forum." ${ }^{58}$ But even under this broader formulation, according to Alden, states are immune only from "suits." At least in theory, they may remain subject to private damage liability. I shall discuss in turn these two possible ways to escape the conclusion that, after Alden, states are immune from federally imposed damage liability to individuals.

In Hall, the California courts entertained an action against the State of Nevada based on California law and refused to give effect to a Nevada law protecting the state from liability beyond a certain amount. ${ }^{39}$ The Court held that nothing in the federal Constitution protected Nevada from such a suit or required California to recognize Nevada's law concerning sovereign immunity. ${ }^{60}$ Hall thus leaves open the possibility that the states' federal obligations may be enforced against them through private suits in the courts

56. 440 U.S. 410 (1979).

57. Because states may not discriminate against claims based on federal law, see McKnett v. St. L. \& S.F. Ry., 292 U.S. 230, 234 (1934), if states are indeed subject to such liability, then state courts may be constitutionally required to entertain suits against sister states based on federal law if they entertain suits against sister states based on analogous state laws. The "valid excuse" exception, however, would appear to permit states to deny their own courts jurisdiction over suits against sister states based on federal law even if they consent to suits against themselves based on the same federal law. See Howlett v. Rose, 496 U.S. 356, 369 (1990) (quoting Douglas v. New Y., N.H. \& H.R. Co., 279 U.S. 377, 387-88 (1929)); cf. Jackson, Principle and Compromise, supra note 3 (suggesting that Alden means that states can insist on sovereign immunity in their own courts in suits based on federal law even if they have consented to analogous state-law claims); infra note 68 (suggesting that Hall may permit suits against sister states only if states waive their own immunity from similar suits).

58. Alden, $119 \mathrm{~S}$. Ct. at 2262.

59. See Hall, 440 U.S. at $412-13$.

60. See id. at 426 . 
of sister states. Indeed, if State $A$ does subject State $B$ to private damage suits for violation of federal law, State $B$ may be required under the Full Faith and Credit Clause to enforce State $A^{\prime}$ s judgment against it. ${ }^{61}$ Alden could be interpreted to hold otherwise, ${ }^{62}$ but the Court in Alden distinguished Reich v. Collins as a suit in which the "obligation arises from the Constitution itself" and did not involve "the power of Congress to subject States to suits in their own courts." ${ }^{63}$ The Court could thus conceivably hold that just as the states' entitlement to sovereign immunity in their own courts is subject to the remedial requirements of the Due Process Clause, so too is it subject to the Full Faith and Credit Clause.

Although Hall does leave open this mechanism for enforcing a federally created liability of the states, I shall not dwell on this possible ground for concluding that the Court did not embrace the immunity-fromliability view. First, Alden itself suggests that Hall may not survive long. Although the Court in the end phrased its holding narrowly (apparently because of Hall), some of the support it cited for its holding is as inconsistent with Hall as with the position urged by the plaintiffs in the case. For example, the Court relied on a number of cases making the "sweeping" statement that states cannot be sued by individuals without their consent. ${ }^{64}$ It also relied on its statement in Beers $v$. Arkansas that " [i]t is an established principle of jurisprudence in all civilized nations that the sovereign cannot be sued in its own courts, or in any other, without its consent and permission." ${ }^{65}$ Even more to the point was its quotation from Cunningham v. Macon \& Brunswick Railroad that "[i]t may be accepted as a point of departure unquestioned, that neither a State nor the United States can be sued as defendant in any court in this country without their consent." ${ }^{66}$ Finally, the Court stressed " the indignity of subjecting a State to the coercive process of judicial tribunals at the instance of private parties,' regardless of the forum." 67 These passages suggest that the constitutional immunity recognized in Alden protects states from being sued in the courts of sister states without their consent. ${ }^{68}$

61. See U.S. CONST. ar. IV, $\S 1$.

62. See Alden, 119 S. Ct. at 2266 (" [W] hold that the States retain immunity from private suit in their own courts ....").

63. Id. at 2259. As discussed further below, the Reich case, and indeed the Court's decision the same day in Florida Prepaid, do appear to be cases in which, in a sense, Congress is subjecting states to suit in their own courts. See infra notes 136-139 and accompanying text.

64. See Alden, 119 S. Ct. at 2262 (citing Great Northem Life Ins. Co. v. Read, 322 U.S. 47, 51 (1944); In re Ayers, 123 U.S. 443, 506 (1887); Board of Liquidation v. McComb, 92 U.S. 531, 541 (1876); Briscoe v. Bank of Ky., 36 U.S. (11 Pet.) 257, 321-22 (1837)).

65. Alden, 119 S. Ct. at 2262 (quoting Beers v. Arkansas, 61 U.S. (20 How.) 527, 529 (1858)) (emphasis added).

66. Id. (quoting Cunningham v. Macon \& B.R., 109 U.S. 446, 451 (1883)) (emphasis added).

67. Id at 2264 (quoting Ayers, 123 U.S. at 505) (citations omitted) (emphasis added).

68. Moreover, if sister states were required to enforce in their own courts private judgments obtained against them in the courts of sister states, Hall would also appear to conflict with the 
Second, Alden would be consistent with the immunity-from-liability view even if the Court did not overrule Hall or hold that the Full Faith and Credit Clause does not extend to suits to enforce a sister-state judgment in a state's own courts. Hall leaves open a private remedy against states for violations of federal law, but the remedy would exist if and only if a sister state recognized it. A remedy that exists only by virtue of its recognition by another state would appear to be a state remedy, not a federal remedy. A suit under Hall seeking a remedy for the violation of federal law does not seek to enforce a liability "imposed" by federal law. Even under the broadest interpretation of Hall, therefore, states could still be said to be immune from federal damage liability to individuals. ${ }^{69}$

To be sure, my rejection of this first rationale for denying that Alden embraces the immunity-from-liability view depends on a particular conception of what it means to be under a legal liability. A second possible way to reconcile Alden with the existence of a congressionally imposed liability of states to individuals would be simply to deny that the existence of a federal "liability" requires the availability of a compulsive "suit" to enforce the liability. For example, it is recognized that nations may be "responsible" to other nations for their violations of international law even though no judicial forum exists in which the injured state may maintain an action against the responsible state without the latter's consent. Justice Holmes said in The Western Maid that "[1]egal obligations that exist but cannot be enforced are ghosts that are seen in the law but that are elusive to the grasp." ${ }^{70}$ Perhaps the federal liability exists in the ghostly fashion described by Holmes even though the states' sovereign immunity prevents its enforcement without the states' consent. The care taken by the Alden

Alden Court's emphasis on the importance of allowing states to control their own treasuries. See Alden, 119 S. Ct. at 2264 . Congress could expose all state treasuries to private " raids" merely by persuading a single state of the wisdom of the federal policy. $C f$. id. at 2250 (quoting DAVID P. CuRRIE, The CONSTITUTION IN CONGRESS: THE FEDERALIST PERIOD 1789-1801, at 196 (1997)) (expressing concern about private raids on state treasuries); United States Supreme Court Transcript, Alden (No. 98-436), available in 1999 WL 216178, at *21-22 (same). Congress might even be able to achieve this goal without persuading any state of the wisdom of the federal policy - for example, by offering a state federal money if it agrees to subject itself and sister states to private damage suits in its courts. (The Court in Hall noted that California had "unequivocally waived its own immunity from liability for the torts" to which it was subjecting Nevada. suggesting that a state would not be free to preserve its own immunity while subjecting sister states to liability on the same cause of action. See Nevada v. Hall, 440 U.S. 410,424 (1979).) Since states are not persons for purposes of the Due Process Clause, see Republic of Argentina v. Weltover, Inc., 504 U.S. 607, 619 (1992); South Carolina v. Katzenbach, 383 U.S. 301, 323-24 (1966), a state could apparently authorize its courts to entertain suits against sister states without regard to the existence of "minimum contacts." See generally International Shoe Co. v. Washington, 326 U.S. 310 (1945). Nor would the dormant Commerce Clause pose an obstacle, since by hypothesis Congress will have "authorized" any such burden on interstate commerce.

69. This is why $I$ have never regarded Hall as inconsistent with the immunity-from-liability theory. See Vázquez, supra note 14 , at 1700 n.77, 1711 n.131.

70. 257 U.S. 419,433 (1922). 
Court not to characterize its holding as an immunity from liability suggests that the majority may have viewed it that way.

But I doubt that even Holmes would regard such obligations as legal ones. ${ }^{71}$ In any event, it appears that the Framers would not have regarded an obligation of a state that cannot be enforced without the state's consent as a legal one. The Framers distinguished a law from a "mere treaty" in that the latter depended for its efficacy on the good faith of the parties." The statements by Hamilton and others relied on by the Cour in Hans and later in Seminole Tribe equate the existence of sovereign immunity with the absence of a right of action-indeed, the absence of a primary legal duty. ${ }^{73}$ For example, Hamilton wrote in The Federalist No. 81 that

there is no color to pretend that the State governments would, by adoption of [the Constitution], be divested of the privilege of paying their own debts in their own way, free from every constraint but that which flows from the obligations of good faith. The contracts between a nation and individuals are only binding on the conscience of the sovereign, and have no pretensions to a compulsive force. They confer no right of action independent of the sovereign will. ${ }^{74}$

Because of the states' immunity, individuals had no "right of action" against the states. Because the states' contracts depended for their efficacy on the states' good faith, they lacked "compulsive force." In other words, they did not create legal obligations at all. ${ }^{75}$

If anything emerges with clarity from the convention and ratification debates, it is that the Framers did not rely on the states' good faith to secure the efficacy of the federal obligations of the states. Such reliance was, indeed, the chief problem with the Articles of Confederation and the principal reason the Framers decided to write a new constitution:

There was a time when we were told that breaches by the States of the regulations of the federal authority were not to be expected; that a sense of common interest would preside over the conduct of the

71. The statement, after all, appears in an opinion concluding that a ship that negligently caused another ship injury while being operated by the sovereign did not incur any liability as a result.

72. THE FEDERALIST No. 33, supra note 18, at 172 (Alexander Hamilton).

73. See also Idaho v. Coeur d'Alene Tribe, 521 U.S, 261 (1997); Blatchford v. Native Village, 501 U.S. 775 (1991); Principality of Monaco v. Mississippi, 292 U.S. 313 (1934).

74. THE FEDERALIST NO. 81, supra note 18, at 456 (Alexander Hamilton).

75. See Hamilton's statement in The Federalist No. 33 that a "mere treary." unlike a law, is "dependent on the good faith of the parties," id. at 172, and Gouverneur Morris's statement that. unlike "a mere compact resting on the good faith of the parties," a "narional, supreme, Govt... [has] a compleat and compulsive operation." 1 THE RECORDS OF THE FEDERAL CONVENTION OF 1787, at 34 (Max Farrand ed., 1966). 
respective members, and would beget a full compliance with all the constitutional requisitions of the Union. This language, at the present day, would appear as wild as a great part of what we now hear from the same quarter will be thought, when we shall have received further lessons from that best oracle of wisdom, experience. It at all times betrayed an ignorance of the true springs by which human conduct is actuated, and belied the original inducements to the establishment of civil power. Why has government been instituted at all? Because the passions of men will not conform to the dictates of reason and justice without constraint. $^{76}$

This history is difficult to square with one of the reasons the Alden Court gave in support of its holding:

We are unwilling to assume the States will refuse to honor the Constitution or obey the binding laws of the United States. The good faith of the States thus provides an important assurance that "[t]his Constitution, and the Laws of the United States which shall be made in Pursuance thereof . . . shall be the supreme Law of the Land." 77

The Court's invocation of "good faith" as a mechanism for securing the status of the states' federal obligations as "Law of the Land" offers some basis for thinking that the Court regarded the states as being under a federal legal liability to individuals even though their sovereign immunity precluded the enforcement of this liability without their consent. ${ }^{78}$ But this

76. THE FEDERALIST No. 15, supra note 18, at 78 (Alexander Hamilton). For additional citations, see Carlos Manuel Vázquez, Treaty-Based Rights and Remedies of Individuals, 92 COLUM. L. REV. 1082, 1097-101 (1992).

77. Alden v. Maine, 119 S. Ct. 2240, 2266 (1999) (quoting U.S. CoNST. art. VI).

78. The Court's failure to overrule its decision in Hilton may offer further support for this view. As noted above, the Court in Hilton held that FELA did subject states to "monetary liability" to individuals. See Hilton v. South Carolina Pub. Rys. Comm'n, 502 U.S. 197, 207 (1991). In Alden, the Court interpreted Hilton as having turned on the states' consent to being sued in their own courts under FELA. See Alden, $119 \mathrm{~S}$. Ct. at 2258 . If the Court embraces both views, then perhaps it does believe that states can be said to be subject to a federal legal liability. even if that liability can be enforced against them only if they consent. $C f$. Vazquez, supra note 14, at 1788-89 (anticipating the Alden holding and suggesting that the Court might reconcile such a holding with Hilton by denying that a legal obligation must be enforceable without consent, but rejecting that position as incompatible with the Framers' view of law). But Alden appears to reject at least some aspects of the Court's analysis in Hilton. For example, the Court in Hilton had viewed the issue before it as whether states were entitled to "immunity from state-court suit" under FELA, 502 U.S. at 203, and it held that they were not entitled to such immunity, stating that "when . . . a federal statute does impose a liability on the States, the Supremacy Clause makes that statute the law in every State, fully enforceable in state court," id. at 207. Alden holds that states are entitled to immunity from state-court suit under statutes like FELA, and hence such statutes are not "fully enforceable" against the states in state courts. If Alden requires a rejection of these aspects of Hilton, then there appears to be little reason to believe that the Court still adheres to the notion that FELA imposes "monetary liability" on the states. 
invocation is highly problematic precisely because it conflicts so directly with the Framers' understanding of what it means for an obligation to have legal status.

In the end, however, the Court's confidence in the states' good faith appears to have played a negligible role in its analysis. The quoted passage refers to the primary obligations imposed by federal law on the states, not the remedial obligations. Although the expected good faith of the states gave the majority some comfort, the Court went on to recognize that the efficacy of these obligations does not rest on good faith. The Court stressed as well that "the plan of the Convention" included mechanisms for enforcing federal obligations even against recalcitrant states." These mechanisms include suits by the federal government or by sister states in federal court, suits against state officials by private parties seeking prospective relief, and suits by private parties seeking damages from state officials. ${ }^{80}$ The Court concluded that these mechanisms provided sufficient assurance that the federal obligations of the states would be effective, while offering due protection to the states' dignity and their treasuries. ${ }^{81}$ The Court's reliance on these compulsory mechanisms to enforce the primary obligations is consistent with the idea that those obligations are legally binding on the states (in the Framers' sense) even though the states remain immune from private damage liability under federal law. On the other hand, the claim that a liability of states to private individuals exists as a legal matter even though it cannot be enforced by such individuals without the states' consent is inconsistent with the Court's ultimate recognition (and the Framers' clear view) that compulsory mechanisms of enforcement are necessary to give efficacy to legal obligations of states-indeed, to give such obligations the status of "law." If law is by its nature compulsory, then a liability that depends on the good faith of those subject to the norm is not a legal liability.

Although Alden may be equivocal in this regard, the decision the same day in College Savings Bank establishes that the Court has embraced the immunity-from-liability view, even if the Court does not yet fully realize it. College Savings Bank involved the constitutionality of Congress's abrogation of Eleventh Amendment immunity in the Lanham Act. Under Fitzpatrick v. Bitzer, ${ }^{82}$ Congress may abrogate this immunity pursuant to its power to enforce the Fourteenth Amendment, but under Seminole Tribe, it may not abrogate pursuant to its Article I powers. ${ }^{63}$ In the Lanham Act, Congress abrogated the states' Eleventh Amendment immunity on the

79. Alden, 119 S. Ct. at 2267.

80. See id. at 2267-68.

81. See id. at 2268.

82. 427 U.S. 445,456 (1976).

83. See Seminole Tribe v. Florida, 517 U.S. 44.47 (1996). 
theory that the Act creates property rights that are protected by the Fourteenth Amendment's Due Process Clause. The plaintiff in College Savings Bank argued that the abrogation was valid on this theory, but the argument foundered at the first step. The plaintiff was complaining about the defendant's false advertising of its own products. The Court held that, while the Lanham Act may create some rights that count as property for purposes of the Due Process Clause, such as the rights protected by a trademark ${ }^{84}$ the right that the plaintiff was claiming-the right to be free from pecuniary injury caused by a competitor's false advertising of its own product-is not a property right. ${ }^{85}$

The Court's treatment of the concept of property under the Due Process Clause is the focus of Part III. For now, the important point is that the Court completely ignored another right that the plaintiff was claiming: the right to damages from the defendant for alleged false advertising. ${ }^{86}$ Congress clearly purported to establish such a right in the Lanham Act. ${ }^{87}$ The Court's precedents establish that a chose in action is a property right. ${ }^{88} \mathrm{~A}$ chose in action is a "right to recover ... money." ${ }^{89}$ The Court's failure to consider the plaintiff's right to damages is explicable on the theory that Congress lacked the power to confer such a right. And this, in turn, is explicable on the theory that, in the light of Alden and Seminole Tribe, sovereign immunity protects states from being subjected by Congress to damage liability to individuals.

The other possibility is that a federal liability exists but cannot be enforced without the state's consent. But if such a "liability" were deemed a legal one, it would be unclear why the corresponding right to damages would not count as a property right for due process purposes. One answer may be that even if a right to damages is a "legal" right, it is not a property right unless the rightholder also has the capacity to enforce it in court. An alternative definition of "chose in action" is a "right of bringing an

84. See College Sav. Bank v. Florida Prepaid Postsecondary Educ. Expense Bd., 119 S. Ct. 2219,2224 (1999).

85. See id. at 2225 .

86. See id. at $2224-25$.

87. See 15 U.S.C. $\S 1122$ (b) (1994).

88. See, e.g., Richards v. Jefferson County, 517 U.S. 793, 804 (1996) (noting that a "chose in action" is a "protected property interest in its own right"); Phillips Petroleum Co. v. Shutts, 472 U.S. 797, 807 (1985) (" $[\mathrm{A}]$ chose in action is a constitutionally recognized property interest ....").

89. BLACK's LAW DictionaRY 219 (5th ed. 1979); see also 2 William BLACKSTONE, COMMENTARIES *397 ("Thus money due on a bond is a chose in action...."); THOMAS BLOUNT, NOMO-LEXICON: A LAW-Dictionary (London, Thomas Newcomb 1670) ("Chose in action is a thing incorporeal and onely a right, as an annuity, obligation for Debt ..."); 1 JOHN BOUVIER, A LAW DICTIONARY 227 (Philadelphia, Childs \& Peterson 1856) (defining chose in action as a right "to receive or recover a debt, or money, or damages for breach of contract. or for a tort connected with contract"). 
action." ${ }^{90}$ Perhaps the Court would say that the cases recognizing that a chose in action is property use the term in this second sense and thus merely restate the well-established principle that a cause of action is a property right. ${ }^{91}$ Thus, it might be argued, the plaintiff in College Savings Bank had a legal right to damages but lacked a property right because, in the light of Alden, it lacked the power to bring the state into court. Florida Prepaid, however, establishes that a person may have a property right against the state even if sovereign immunity prevents the individual from maintaining an action for damages against the state without its consent. The Court's failure even to consider whether the right to damages created by Congress qualifies as a property right, even if it is unenforceable in court, suggests that the Court understood its holding in Alden as negating any such right.

That, at any rate, appears to be how the majority in College Savings Bank understood its holding, for it expressly described the issue in the case as whether "Congress can make Florida liable to private parties for false or misleading advertising." 92 Thus, the Court did not consider whether the right to damages that Congress created was a basis for abrogating the state's sovereign immunity on a due process theory, because, in its view, such liability is exactly what sovereign immunity protects the states from. That is the immunity-from-liability view. ${ }^{93}$

90. BLACK'S LAW DICTIONARY, supra note 89, at 219; see also BLOUNT, supra note 89 (" [G]enerally all Causes of Suit for any Debt or Duty. Trespass or Wrong. are to be accounted Choses in action.").

91. See, e.g., Tulsa Prof'l Collection Servs. v. Pope, 485 U.S. 478. 485 (1988) (finding a property right in a cause of action against an estate for an unpaid bill); Logan v. Zimmerman Brush Co., 455 U.S. 422, 429-30 (1982) (finding a property right to use the adjudicatory mechanism of a fair labor act); Mullane v. Central Hanover Bank \& Trust. 339 U.S. 306. 313 (1950) (defining as property the right to have a trustee "answer for negligent or illegal impairments of [one's] interests"); In re Consolidated United States Atmospheric Testing Litig., 820 F.2d 982, 988-89 (9th Cir, 1987) (acknowledging that a cause of action is a "species of property"); Shanghai Power Co. v. United States, 4 Cl. Cl. 237, 240 (1983) (Kozinski, C.J.) (finding a property right in a claim for the difference between the terms of a settement and the amount the plaintiff believed the claim was worth).

92. College Sav. Bank v. Florida Prepaid Postsecondary Educ. Expense Bd., 119 S. Cl. 2219. 2230 (1999) (emphasis added).

93. Characterizing state sovereign immunity as an immunity from liability may seem strained in the light of Congress's apparent power to establish a system under which the federal government sues to recover money from states that have violated federal law and tums the money over to the individuals injured as a result of the violation. Can it be said that states are immune from "liability" under such a regime? I have characterized state sovereign immunity as an immunity from liability to individuals, as did the Cour in College Savings Bank. But perhaps it would be more accurate to say that state sovereign immunity denies individuals the Iegal right to damages, in the sense that they lack the capacity to enforce any entitiement to such damages. See generally Vázquez, supra note 76, at 1089-91. 


\section{FLORIDA PREPAID AND THE PARTIAL RESURRECTION OF THE FORUM-ALLOCATION VIEW}

On the same day that it adopted the immunity-from-liability view in Alden, the Court appears to have partially resurrected the forum-allocation view with respect to a subset of congressionally imposed obligations of the states: those that give rise to correlative "property" rights within the meaning of the Due Process Clause. Indeed, in some respects, the states' remedial obligations under the Due Process Clause are broader than their remedial obligations under the forum-allocation view. Under the latter view, the states would have been required to entertain private damage actions in their own courts if Congress created a right to damages. Florida Prepaid appears to hold that, with respect to congressionally created property rights, states are obligated to provide an adequate remedy to individuals even if Congress has not created a damages remedy. As long as Congress has imposed a primary obligation that gives rise to a "property" right, the Due Process Clause itself requires the states to provide an adequate remedy.

The plaintiff in Florida Prepaid was the College Savings Bank, the same bank that was the plaintiff in College Savings Bank. It alleged that the defendant, an agency of the State of Florida, had infringed its patent rights, and it sued for damages in federal court. ${ }^{94}$ The patent laws give the federal courts exclusive jurisdiction over infringement claims. ${ }^{95}$ In 1992, Congress abrogated the states' Eleventh Amendment immunity from suit in federal court. ${ }^{96}$ At that time, the Court had not yet overruled its holding in Union Gas that Congress possesses the power to abrogate Eleventh Amendment immunity pursuant to its Article I legislative powers. ${ }^{97}$ But, perhaps anticipating Union Gas's demise, Congress justified the abrogation of Eleventh Amendment immunity as an "enforcement" of the Fourteenth Amendment. ${ }^{98}$ Its theory was that patent rights are "property" rights within the meaning of the Fourteenth Amendment's Due Process Clause, and accordingly an abrogation of state immunity from federal jurisdiction was a valid measure to "enforce" the state's obligations under that clause."

Florida did not deny that patents were property. Instead, it urged the Court to hold that Congress lacks the power to abrogate Eleventh Amendment immunity to "enforce" the states' obligations under the Due Process Clause with respect to "property" rights created by Congress under

94. See Florida Prepaid Postsecondary Educ. Expense Bd. v. College Sav. Bank, 119 S. Ct. $2199,2223$.

95. See 28 U.S.C. $\$ 1338$ (1994).

96. See 35 U.S.C. $\& 296$ (1994).

97. The Court overruled Union Gas in Seminole Tribe v. Florida, 517 U.S. 44 (1996).

98. See S. REP. NO. 102-280, at 7-8 (1992).

99. See id.; see also Florida Prepaid, 119 S. Ct. at 2208 n.7. 
Article I. ${ }^{100}$ Allowing Congress to abrogate sovereign immunity to enforce the states' obligations regarding property rights created under Article I, Florida argued, would circumvent the holding in Seminole Tribe that Congress lacks the power to abrogate immunity pursuant to Article I. ${ }^{10 t}$ Rejecting that argument, the Court expressly recognized that Congress has the power to abrogate sovereign immunity to enforce the states' due process obligations concerning property rights that it has created under Article I. ${ }^{102}$

But, the Court held, a state deprivation of the plaintiff's property right is not a sufficient predicate for an abrogation of sovereign immunity. The Court reiterated its holding in City of Boerne v. Flores ${ }^{103}$ that Congress's power under Section 5 is " "remedial' in nature," ${ }^{10 s}$ and said that an abrogation of sovereign immunity is "appropriate" legislation under Section 5 only if it is "tailor[ed] ...to remedying or preventing ... conduct" that "transgress[es] the Fourteenth Amendment's substantive provisions." ${ }^{105}$ Congress said that it had abrogated the states' Eleventh Amendment immunity from patent-infringement suits to enforce the Due Process Clause, but that clause, the Court stressed, does not prohibit deprivations of property; it prohibits such deprivations only if accomplished "without due process of law." Citing earlier procedural due process decisions, the Court emphasized that a state can sometimes satisfy its obligation to provide "due process" by providing an adequate remedy in its own courts. ${ }^{106}$ The Court struck down Congress's abrogation of sovereign immunity from patent-infringement claims for two reasons: First, Congress lacked sufficient evidence that states were both infringing federally protected patent rights and failing to provide the "adequate" remedy required by the Due Process Clause; and second, it did not limit the abrogation to cases involving "unremedied patent infringements by the States." 107

For present purposes, the most interesting aspect of Florida Prepaid is not its holding that Congress may abrogate sovereign immunity to "enforce" the guarantee of procedural due process, but rather its holding regarding what the Due Process Clause requires in the first place. The Court's recognition that the Due Process Clause requires the states to provide an adequate remedy to individuals when the states "deprive" them

100. See Florida Prepaid, 119 S. Ct. at 2208.

101. In support of this argument, Florida relied on Vázquez, supro note 14, at 1744-46. See Brief for Petitioners, Florida Prepaid (No. 98-531), available in 1999 WL 86846. at *19.

102. See Florida Prepaid, 119 S. C. at 2208.

103. 521 U.S. 507 (1997).

104. Florida Prepaid, 119 S. Ct. at 2206.

105. Id. at 2207.

106. See id. at 2208-09 (relying on Zinermon v. Burch, 494 U.S. 113 (1990); Hudson v. Palmer, 468 U.S. 517 (1984); and Parratt v. Taylor, 451 U.S. 527 (1981)).

107. Id. at 2207 (emphasis added). 
of property rights created by Congress threatens a substantial resurrection of the forum-allocation view.

The resurrection is incomplete for two reasons. First, it applies only to "property" and "liberty" rights. The opinion in College Savings Bank makes it clear that not all federally imposed obligations are "property" rights. The Court did not say anything about liberty, but presumably the Court does not regard all federal rights as liberty for purposes of the Due Process Clause. The present contours of the concept of "property" are the principal subject of Part III. Second, the Due Process Clause requires a remedy only when the state has "deprived" people of property rights. The Court in Florida Prepaid stressed that a "deprivation" occurs only when the state acts intentionally. ${ }^{108}$ Neither Florida Prepaid nor the decisions on which it relies offer much guidance about the precise mental state that produces a "deprivation," but it is clear that negligent injuries to property do not implicate the Due Process Clause and thus do not require an "adequate" remedy.

The opinion in Florida Prepaid also leaves it unclear what an "adequate" remedy is. It seems clear that the Court is contemplating monetary relief. ${ }^{109}$ It is also clear that an adequate remedy is less than what Congress authorized in the patent laws-treble damages and attorneys' fees. ${ }^{110}$ But, beyond that, the meaning of "adequacy" is uncertain. It is possible that an "adequate" remedy under the Due Process Clause is equivalent to "just compensation" under the Takings Clause," consisting of compensatory but not punitive relief. The due process regime thus differs from the forum-allocation regime in that the remedy required by the Due Process Clause is not necessarily the same as the remedy Congress specified in the statute. It may be either narrower or broader. ${ }^{112}$

Among the other ambiguities that remain after Florida Prepaid is whether the "adequate" remedy required by the Due Process Clause is a remedy against the state itself or merely its officers. Some of the Court's procedural due process cases suggest that the Due Process Clause entitles persons deprived of property by the state to a remedy against the state itself. McKesson, for example, was a case brought by a taxpayer seeking a refund from the state on the ground that the state tax was unconstitutional. The

108. See id. at 2209.

109. See id. at $2209 \&$ n. 9 .

110. See id. at 2209.

111. See U.S. CoNST. amend. V.

112. That it may be broader appears to follow from the Court's rejection of the "bitter with the sweet" interpretation of the Due Process Clause advocated by then-Justice Rehnquist's plurality opinion in Arnett v. Kennedy, 416 U.S. 134, 152-54 (1974), under which the Due Process Clause would protect only such procedures as the legislature provided for when it created the right. See Cleveland Bd. of Educ. v. Loudermill, 470 U.S. 532, 541 (1984) (rejecting Justice Rehnquist's "bitter with the sweet" theory); Vázquez, supra note 14, at 1768-70 (discussing the Court's rejection of the "bitter with the sweet" theory); infra Part III. 
state courts agreed that the state tax violated the dormant Commerce Clause, ${ }^{113}$ but held that full compensatory relief was not required under Florida law. ${ }^{114}$ The Supreme Court reversed, holding that, if the state denies taxpayers a predeprivation opportunity to challenge a tax's validity, then the Due Process Clause requires a postdeprivation hearing and, if the tax was invalid-and no other remedy would cure the violation-a refund. ${ }^{115}$ This case and others ${ }^{116}$ suggest that the remedy required by the Due Process Clause is a remedy against the state.

The Parratt v. Taylor line of procedural due process cases, however, suggests that the Due Process Clause is satisfied as long as the state makes available a damage remedy against responsible state officials. Parratt was a suit brought by a prisoner under $\S 1983^{117}$ seeking damages for a state official's destruction of his hobby kit. ${ }^{118}$ The prisoner argued that the state officer was liable under $\S 1983$ because he had deprived the prisoner of his property without due process. The Court agreed that the hobby kit was property, but held that, if the deprivation was random and unauthorized, as it was in that case, ${ }^{119}$ the state satisfies its obligations under the Due Process Clause by making available a postdeprivation remedy. ${ }^{120}$ In Parratt, Nebraska had made available a postdeprivation remedy against the state itself, ${ }^{121}$ but subsequent cases indicate that a postdeprivation remedy against the officer suffices for due process purposes. ${ }^{122}$

In an earlier article, I suggested that these two lines of due process cases could be reconciled, and other doctrinal conundrums solved, if McKesson were interpreted as holding that the remedy required by the Due Process Clause is a remedy against state officials rather than the state

113. See McKesson Corp. v. Division of Alcoholic Beverages \& Tobacco, 496 U.S. 18, 2526 (1990).

114. See id. at 26.

115. See id. at 51-52.

116. See, e.g., Newsweek v. Florida Dep't of Revenue, 522 U.S. 142 (1998) (per curiam) (requiring Florida to provide meaningful backward-looking relien); Reich v. Collins, 513 U.S. 106,114 (1994) (requiring the same relief from Georgia).

117. 42 U.S.C. $\$ 1983$ (1994).

118. See Parratt v. Taylor, 451 U.S. 527, 530 (1981).

119. The destruction of the hobby kit was alleged to have been negligent. The Court in Parratt held that such negligent conduct can be a "deprivation" for due process purposes. See id. at 534-35. This holding was later reversed in Daniels v. Willianis. 474 U.S. 327. 330 (1986), but the Parratt precedent remains applicable to willful conduct that is "random and unauthorized." See Zinermon v. Burch, 494 U.S. 113, 138 (1990): Hudson v. Palmcr, 468 U.S. 517.534 (1984).

120. See Parratt, 451 U.S. at 544.

121. See id. at 530.

122 See Hudson, 468 U.S. at 520 n.l; see also Zinermon, $49+$ U.S. at 115 (citing Coun precedent that a "postdeprivation tort remedy" suffices for random and unauthorized deprivations); Richard H. Fallon, Jr., Some Confusions Abous Due Process, Judicial Review, and Constitutional Remedies, 93 COLUM. L. REv. 309, 349 (1993) (suggesting that Parratt requires federal courts "to develop constitutional standards defining the scope of various officials" liabilities"); Vázquez, supra note 14, at 1771-72 n.386. 
itself. ${ }^{123}$ As long as a state makes available a remedy against officials, it is not required by the Due Process Clause to entertain suits against itself. But if it immunizes its officials from liability, or if it otherwise burdens the right of action against the official-for example, by structuring its tax-collection system in such a way as to leave it unclear which official is liable-then it must substitute a suit against the state itself. On this view, the Court in McKesson and like cases held that the remedy must come from the state itself because the state had "consented" to the remedy by establishing a procedure for obtaining a refund of taxes from the state. The Due Process Clause would be satisfied, however, by a regime affording meaningful relief against state officials.

The decision in Florida Prepaid provides slight additional support for the officer-liability interpretation of McKesson. The Court in Florida Prepaid stressed that the Due Process Clause is implicated only if persons are intentionally deprived of their property. The Court did not elaborate on the state-of-mind requirement, but the intent standard is susceptible of being interpreted as establishing the same standard of liability under the Due Process Clause as the Court has elaborated for recovery under $\S 1983$ against individual state officers who violate federal law. In Harlow $v$. Fitzgerald, ${ }^{124}$ the Court held that officials are subject to damage liability only when they violate "clearly established" federal law. Although the "clearly established" standard, especially as interpreted in such cases as Anderson v. Creighton, ${ }^{125}$ seems more stringent than the Due Process Clause's "intentional" or "nonnegligent" standard, this Term's cases suggest a convergence. In Alden, the Court described the "clearly established" standard as determining when a wrong is "fairly attributable" to the officer. ${ }^{126}$ This may not signal a weakening of the standard, but it does indicate that the Court perceives it as reflecting a minimum standard of fairness. On the other hand, the opinion in Florida Prepaid suggests a possible transmutation of the "nonnegligent" standard into a "recklessness" standard, which begins to resemble more closely the "clearly established" standard, as it has actually been applied. ${ }^{127}$

This possible convergence offers some support for the claim that the remedy required by the Due Process Clause is a remedy against state officials, but the support is very weak. First, it is far from clear that the

123. See Vázquez, supra note 14 , at 1770.

124. 457 U.S. $800,818(1982)$.

125. 483 U.S. 635 (1987).

126. Alden v. Maine, 119 S. Ct. 2240,2267 (1999).

127. The Court in Florida Prepaid cited the fact that Congress did not " focus on instances of intentional or reckless infringement on the part of the States" as indicating that it was not focusing on violations of due process. Florida Prepaid Postsecondary Educ. Expense Bd. v. College Sav. Bank, 119 S. Ct. 2199, 2209-10 (1999). On the other hand, it suggested elsewhere that "nonnegligent" infringement may be the standard. See id. at 2210. 
Court has the same standard in mind for the two contexts. ${ }^{128}$ Moreover, the claim that the Due Process Clause requires a remedy only if the state or its officers have violated clearly established state law is in tension with the Court's holding in Harper $v$. Virginia Department of Taxation ${ }^{129}$ that the Court's constitutional interpretations must be applied retroactively to pending tax refund suits if the interpretation was applied to the parties in the case in which it was rendered. ${ }^{130}$ Although this holding may technically be compatible with a remedial rule under which damages would be unavailable to taxpayers if the constitutional interpretation that rendered the law invalid had not been clearly established at the time the tax was collected, ${ }^{131}$ the latter rule would appear to render the retroactivity holding wholly irrelevant. ${ }^{132}$ The Court could reconcile Harper with a "clearly established" standard for other types of property cases by limiting the retroactivity holding to suits seeking restitution of taxes paid without a prior hearing, ${ }^{133}$ but neither Harper nor Florida Prepaid alludes to such a limitation. In view of the weakness and ambiguity of the support for the

128. It should be noted, moreover, that this convergent standard, if such it is, would be only a default rule. The due process standard represents a mandatory federal floor. The officers" qualified immunity for violations of federal law that were not clearly established, on the other hand, has been treated by the Court as a subconstitutional ceiling. Unless the Court means to constitutionalize the officers' qualified immunity, cf. Seminole Tribe v. Florida, 517 U.S. 44, 71 n.15 (1996) (suggesting that this immunity may have constitutional underpinnings). Congress would have the power to dispense with it and render state officials liable for violations of notclearly-established federal law. If so, then the convergent standard would apply unless Congress establishes a more lenient one.

129. 509 U.S. 86 (1993).

130. See id. at 97. The Court thus rejected the position of the plurality in American Trucking Ass'ns v. Smith, 496 U.S. 167, 183 (1990), under which constitutional interpretations were held not to be retroactively applicable if the state had reasonably relied on the prior construction.

131. Cf. James B. Beam Distilling Co. v. Georgia, 501 U.S. 529, 544 (1991) tholding that a new constitutional interpretation applies retroactively, but expressly reserving questions of remedy).

132. Compare Reynoldsville Casket Co. v. Hyde, 514 U.S. 749 (1995), in which the Cour rejected a state's attempt to deny on state-law "remedial" grounds a remedy for a violation of a constitutional ruling that the Court had found to be retroactively applicable to the case at hand. Although the Court recognized that some state-law remedial limitations might be valid, it held that such limitations are invalid if they are based on the same considerations that underlie federal retroactivity doctrine. To hold otherwise, the Cour said, would reduce the fedenal retroactivity rule to "symbolic significance." Id. at 753. Although this decision does not bear direculy on the applicability of a federal remedial limitation of damage relief to cases involving a violation of clearly established federal law, its reasoning is in tension with the existence of such a limitation. Cf. RICHARD H. FALLON ET AL., HART \& WECHSLER's THE FEDERAL COURTS AND THE FEDERAL SYSTEM 853 (4th ed. 1996) (suggesting that Reynoldsville Casket "cast doubt on the permissibility of denying relief, as a matter of remedial discretion, for violation of a "novel' constitutional rule"). On the other hand, the relief that the state coun had denied in that case was essentially prospective relief; the Court's holding is thus consistent with the view that damage relief is available against the state for deprivations of property and liberty that violate a retroactively applicable principle of federal law only if the federal-law principle was clearly established.

133. See Richard Fallon \& Daniel Meltzer, New Law, Non-Rerroactivity; and Constitutional Remedies, 104 HARV. L. REV. 1731, 1824-33 (1991). 
officer-liability view in Florida Prepaid, the remainder of my analysis will assume that the Court did not reject the prevailing interpretation of McKesson, under which the adequate postdeprivation remedy required by the Due Process Clause is a remedy against the state itself.

The practical difference between the officer-liability and governmentliability regimes is in any event probably not great. ${ }^{134}$ As noted, an officerliability regime would presumably be adequate only if it were reasonably clear which officers would be personally liable for infringements. In such circumstances, however, the relevant officers would tend to steer clear of depriving persons of property or liberty. Since excessive caution would likely redound to the detriment of the states, the states would find it necessary to offer to indemnify officers for any (or at least some) federal liabilities. States could pass statutes undertaking to reimburse officers under given circumstances, or they could agree to reimburse them in employment contracts. Alternatively, they could pay the officers' liability-insurance premiums. Regardless of which scheme is adopted, the property holder will be assured of substantial payment, and the financial burden will ultimately be borne by the state. ${ }^{135}$ In the end, de jure officer liability is likely to mean de facto state liability. If so, it may simply be easier for all concerned for the state to establish an adequate remedy against itself. ${ }^{136}$

Whether Florida Prepaid resurrects the forum-allocation view for deprivations of liberty and property depends as well on the resolution of another ambiguity in the Court's decision. Under the forum-allocation view, the states are required to entertain in their own courts suits against themselves seeking remedies required by federal law, and, if they fail to

134. See John Jeffries, In Praise of the Eleventh Amendment and Section 1983, 84 VA. L. REV. 47, 60-68 (1998); Vazquez, supra note 14, at 1790-804. This would certainly be the case if the same standard of liability and state-of-mind requirement applied under the Due Process Clause in suits against the state as in suits against the officer. If the officer were entitled to an immunity for violations of not-clearly-established law, but the state were liable for all nonnegligent violations, the regimes would differ to a greater extent. Even if the point of giving the officer a broader immunity were to reduce the risk of overdeterrence attributable to (1) the added embarrassment the officer might suffer at being personally named a defendant and (2) the (slight) risk that the officer might actually have to pay the victim some money from his own pocket, the officer's immunity would narrow the range of cases for which a remedy would be available. For a comparison of the officer-liability and government-liability regimes in the light of official immunity and indemnification, see Vázquez, supra note 3.

135. For an elaboration of the propositions in this paragraph, see Váquez, supra note 14, at 1801-04. If the state does not find it necessary to make adjustments in its compensation package to officers, that will be because the market for such jobs has already fully accounted for the officers' potential liability for deprivations of property or liberty.

136. If the remedy required by Due Process were a remedy against the official, then, strictly speaking, Florida Prepaid would not resurrect the fonum-allocation view, as that view related to suits against the state itself. Suits against officers did not fall within the states' immunity under either the forum-allocation view or the immunity-from-liability view. Of course, if the Court were to extend sovereign immunity to suits against state officers, then Alden would mean that officers would not be liable, but Florida Prepaid, if read to embrace the officer-liability interpretation of McKesson, would partially resurrect the forum-allocation view. 
provide such remedies, the Supreme Court may reverse their judgments on appeal. The Court in Alden held that sovereign immunity protects the states from suits in their own courts seeking monetary relief. Florida Prepaid would resurrect for property and liberty interests the scheme rejected in Alden only if the Court were envisioning that the states would be required to provide a remedy in their own courts for intentional deprivations of property or liberty, notwithstanding any claim of sovereign immunity, and that the Supreme Court could reverse state-court judgments that fail to provide the remedy on sovereign immunity grounds. Is that the regime that the Court was contemplating?

It appears to be. To insist on sovereign immunity is to deny a remedy; if the Due Process Clause requires the remedy, it precludes a defense of sovereign immunity. ${ }^{137}$ Perhaps a state would be permitted to insist on sovereign immunity if it substituted an adequate remedy against the officer, but, as noted, it is likely that states that permit suits against officers would find themselves footing the bill anyway. At any rate, to insist on sovereign immunity without affording an adequate alternative remedy would appear to be a violation of the obligation under the Due Process Clause to provide an adequate remedy. If the state denies a remedy on sovereign immunity grounds, or provides an inadequate remedy, presumably the Supreme Court may review the case and reverse on the ground that the state courts committed legal error in giving effect to the claim of sovereign immunity. ${ }^{138}$ That the Court contemplated this result is suggested by its treatment of Reich in Alden. Reich was among the cases to hold that the Due Process Clause in certain circumstances requires a damage remedy against the state. As discussed above, the Court in Alden distinguished the case as one in which the remedy was required by the Constitution-in that case the Due Process Clause itself. The language in Reich that the Court distinguished affirmed that if the Due Process Clause requires a remedy, then the states must provide it, "the sovereign immunity States traditionally enjoy in their own courts notwithstanding." 139

An alternative view would be that the Due Process Clause requires the state to provide the remedy, but that a state's invocation of sovereign immunity will be respected by the Supreme Court on direct review. On this

137. See Reich v. Collins, 513 U.S. 106, 109-10 (1994).

138. The Court this Term unanimously reaffirmed the holding of McKesson and other cases that the Eleventh Amendment does not limit the Supreme Court's appellate jurisdiction. See South Cent. Bell Tel. Co. v. Alabama, 119 S. Ct. 1180.1184 (1999).

139. Reich, 513 U.S. at 110; see also Alden v. Maine, 119 S. C. 2240, 2259 (1999). The Court in Alden described Reich as a case in which the Due Process Clause required a remedy against the state because the state had "promised" one. See Alden, 119 S. Cl. at 2259. This may provide additional support for the officer-liability interpretation of McKesson: The Due Process Clause does not always require a remedy against the state itself. but if the state immunizes its officers and substitutes a remedy against the state, then the Due Process Clause requires an adequate remedy against the state. 
view, the state's denial of the remedy required by the Due Process Clause would simply trigger Congress's power to enforce the clause by making the states suable in federal court. This regime would certainly be odd, for it would require the simultaneous acceptance of seemingly contradictory positions: (1) States are obliged by the Due Process Clause to provide an adequate remedy, but (2) states may deny any remedy by invoking sovereign immunity. But this result does find some oblique support in Supreme Court opinions. In Seminole Tribe, for example, the Court indicated that the Supreme Court would have appellate jurisdiction over suits against states in the state courts only if the states had consented to suit. ${ }^{140} \mathrm{~A}$ state that invokes sovereign immunity is not consenting to suit. And in Coeur d'Alene, Justice Kennedy elaborated a conception of Ex parte Young as serving a sort of backstop function, permitting the federal courts to step in when the states refuse to provide the forms of relief necessary to vindicate federal law. ${ }^{141}$ As I have written elsewhere, this is in tension with the idea, supported by General Oil Co. v. Crain, ${ }^{142}$ that the state courts are required by the Constitution to provide such remedies themselves, and that the Supreme Court can reverse their judgments if they do not. ${ }^{143}$ Finally, the Court appears to have embraced the seemingly contradictory positions described above with respect to the sovereign immunity of the United States in takings cases. Although the Court has said that "in the event of a taking, the compensation remedy is required by the Constitution," ${ }^{144}$ it has

140. See Seminole Tribe y. Florida, 517 U.S. 44, 71 n.14 (1996).

141. See Idaho v. Coeur d'Alene Tribe, 521 U.S. 261, 271 (1997) (plurality opinion) ("Where there is no available state forum the Young rule has special significance. In that instance providing a federal forum for a justiciable controversy is a specific application of the principle that the plan of the convention contemplates a regime in which federal guarantees are enforceablc so long as there is a justiciable controversy."); Vázquez, supra note 11, at $49-50$ (cxamining Justice Kennedy's apparent conception of Ex parte Young as a backstop, permitting the federal courts to enforce federal rights that state courts decline to enforce).

142. 209 U.S. 211 (1908).

143. See Vázquez, supra note 11 , at 50 n.319 (discussing Justice Kennedy's treatment of Crain in Coeur d'Alene). This alternative regime would also help explain an otherwise puzzling feature of the Parratt line of cases. As noted, the Court has held in those cases that persons who are deprived of their liberty or property in a random and unauthorized way may obtain a damages remedy in federal court under $\$ 1983$ if positive state law does not offer an adequate postdeprivation remedy. If the Due Process Clause requires the states to provide a remedy, however, and if that requirement were enforceable by the Supreme Court even in the face of a claim of sovereign immunity, then it is unclear why the absence of a positive state-law source for the state-court remedy should matter. See Vázquez, supra note 14 , at 1757 n.331. By contrast, the availability of a damages remedy in federal court under $\S 1983$ would be explicable under a regime in which sovereign immunity bars Supreme Court review of suits against unconsenting states, even if the remedy is required by the Due Process Clause. Under such a regime, the state's failure to provide a remedy required by the Due Process Clause merely triggers a federal power to provide the remedy.

144. First English Evangelical Lutheran Church v. County of Los Angeles, 482 U.S. 304 (1987); see also Paul J. Heald \& Michael L. Wells, Remedies for the Misappropriation of Intellectual Property by State and Municipal Governments Before and After Seminole Tribe: The Eleventh Amendment and Other Immunity Doctrines, 55 WASH. \& LEE L. Rev. 849, 871-73 (1998) (describing states' remedial obligations under the Takings Clause). 
also taken the position that a suit for compensation may not be maintained against the United States in the absence of a waiver of sovereign immunity. ${ }^{145}$

On the other hand, Alden's treatment of Reich suggests that the Seminole Tribe dictum about consent is subject to an exception where the Constitution itself requires the remedy. Justice Kennedy's "backstop" interpretation of Ex parte Young garnered only the vote of the Chief Justice. ${ }^{146}$ More importantly, Kennedy's majority opinion in Alden appears to reject the conception of Ex parte Young that he espoused in Coeur d'Alene. The Alden Court described Crain as a case in which the rule of $E x$ parte Young was "extend[ed]" to "state-court suits." ${ }^{1+7}$ If the majority viewed Ex parte Young as providing a federal-court backstop for cases in which the state courts failed to provide a remedy, it is unclear how that rule could have been "extended" to state-court suits. The majority now appears to accept $C r a i n$ as establishing a right to an injunctive remedy against state officials in state courts, enforceable by the Supreme Court on appeal, paralleling the right to a remedy in federal court recognized in Ex parte Young.

Perhaps the Young-Crain principle is irrelevant anyway because the remedy it recognized was one against the official rather than the state itself, and state sovereign immunity does not extend to officers. But Crain and Young both involved prospective relief, and in that context the distinction between suits against the state and suits against the officer is almost purely formal. Alden, moreover, says that Exparte Young is based on "the premise that sovereign immunity bars relief against States and their officers in both state and federal courts." ${ }^{148}$ It then asserts that Crain and Young establish that "certain suits for declaratory or injunctive relief" may be brought in state and federal courts, notwithstanding this immunity, "if the Constitution is to remain the supreme law of the land." 149 The Court thus seems to be saying that while state sovereign immunity does extend to officials, it is overridden in certain cases based on federal law by the remedial demands of the Supremacy Clause. ${ }^{150}$ Similarly, one could say that the states are not

145. See Lynch v. United States, 292 U.S. 571, 579, 580-82 (1934); Schillinger v. United States, 155 U.S. 163, 168 (1894); see also Webster v. Doe, 486 U.S. 592, 613 (1988) (Scalia, J.. dissenting) ("No one would suggest that, if Congress had not passed the Tucker Act. 28 U.S.C. $\S 1491$ (a)(1), the courts would be able to order disbursements from the Treasury to pay for property taken under lawful authority (and subsequently destroyed) without just compensation."). See generally Robert Brauneis, The First Constitutional Tort: The Remedial Revolution in Nineteenth-Century State Just Compensation Law, 52 VAND. L. REV. 57, $137-39$ (1999) (discussing sovereign immunity constraints on recovery for government takings).

146. See Coeur d'Alene, 521 U.S. at 261, 263-64, 270-71.

147. Alden v. Maine, 119 S. Ct. 2240, 2263 (1999).

148. Id. (emphasis added).

149. Id.

150. See U.S. CONST. art. VI, cl. 2. 
entitled to insist on the sovereign immunity that they would otherwise enjoy from private damage actions if the Due Process Clause requires the remedy. If the state court fails to provide the required remedy, the U.S. Supreme Court may reverse its judgment.

The Court's treatment of the sovereign immunity of the United States in takings cases offers some support for the opposite view. If a constitutionally required damage remedy against the federal government may not be sought in court without the federal government's consent, then perhaps the constitutional scheme does not require the availability of private suits to recover similar constitutionally required remedies against the states without their consent. ${ }^{151}$ There may be ways to reconcile the federal sovereign immunity cases with the position that states may not rely on their sovereign immunity to deny a remedy required by the Constitution, ${ }^{152}$ but this issue need not detain us further. If indeed the United States is immune from suits seeking compensation for unlawful takings of property unless it consents, then the immunity of the states is indisputably different in at least one important respect: As the Court held in Florida Prepaid, the states may be subjected to such suits without their consent if the federal government authorizes them pursuant to Section 5 of the Fourteenth Amendment.

By exercising its abrogation power, Congress can effectively require the states to provide the constitutionally required remedy in their own courts on pain of federal reversal of their judgments. Contrary to the claims of some commentators, ${ }^{153}$ Florida Prepaid does not necessarily hold that abrogation of sovereign immunity is permissible only if the states have engaged in a pattern of prior violations of the Constitution. The opinion suggests strongly that a statute abrogating state sovereign immunity would be valid, even in the absence of a finding of prior violations of the Constitution, if it included the sovereign immunity equivalent of a "jurisdictional hook." In striking down the abrogation in the patent laws, the Court noted that "Congress did nothing to limit the coverage of the Act to cases involving arguable constitutional violations, such as where a State

151. Cf. Pennsylvania v. Union Gas Co., 491 U.S. 1, 34 (1989) (Scalia, J., concurring in part and dissenting in part) ("I think it impossible to find in the scheme of the Constitution a necessity that private remedies [against the states] be expanded . . . to include a remedy not available. for a similar infraction, against the United States.").

152. For example, the Court could resolve the apparent contradiction between First English and the sovereign immunity cases by limiting the former's statement that the Constitution requires the compensation remedy to takings by entities not entitled to sovereign immunity. See Brauneis, supra note 145 , at 138 \& n.344. In other cases, the constitutionally required remedy for an uncompensated taking by the state and federal governments might be the nullity of the taking. combined with a damage remedy against responsible officers. See id. This would be tantamount to an embrace of the officer-liability regime discussed above and in Vázquez, supra note 14.

153. See Laurence H. Tribe, Saenz Sans Prophecy: Does the Privileges or Immunities Revival Portend the Future-or Reveal the Structure of the Present?, 111 HARV. L. REV. 110, 138 (1999) (interpreting Florida Prepaid as permitting abrogation only if it is "narrowly tailored to prevention or remedy of a demonstrable pattem of constitutional violations"). 
refuses to offer any state-court remedy for patent owners whose patents it had infringed." 154 This suggests that Congress could authorize a federalcourt suit against any state that violates the Constitution and fails to afford the constitutionally required remedy. ${ }^{155}$ If Congress can subject a state to an original suit in the lower federal courts in such circumstances, then it can surely take the lesser step of authorizing appeals to the Supreme Court, or presumably to lower federal courts, ${ }^{156}$ from state-court actions seeking the constitutionally required remedy. ${ }^{157}$ Indeed, the Florida Prepaid opinion suggests that Congress may authorize suits against the states directly in federal court if the states do not have a statute on the books authorizing such suits in state courts. ${ }^{158}$ If Congress passes a statute making it clear that states shall be suable directly in federal court unless they have such a statute on the books, then states are very likely to enact such statutes. If Congress provides further that the judgments of such courts shall be reviewable by the Supreme Court or by inferior federal courts, then it will have substantially replicated the forum-allocation regime.

Even if the Due Process Clause requires states to provide a remedy against themselves in their own courts when they willfully deprive

154. Florida Prepaid Postsecondary Educ. Expense Bd. v. College Sav. Bank, 119 S. Cl. 2199,2210 (1999).

155. In striking down the Gun Free School Zones Act in Unired States v. Lopez, the Courn said similarly that the Act "has no express jurisdictional element which might limit its reach to a discrete set of firearm possessions that additionally have an explicit connection with or effect on interstate commerce." United States v. Lopez, 514 U.S. 549. 562 (1995). Congress soon amended the statute to add the missing jurisdictional element. See 18 U.S.C.A. \$ 922(q)(2)(a) (West Supp. 1998) ("It shall be unlawful for any individual knowingly to possess a firearm that has moved in or that otherwise affects interstate or foreign commerce at a place that the individual knows. or has reasonable cause to believe, is a school zone."). The amended statute has been upheld without much controversy. See, e.g., United States v. Shelton. 66 F.3d 991. 992 (8th Cir. 1995) (per curiam).

156. See James E. Pfander, An Intermediate Solution to State Sovereign Immunity: Federal Appellate Court Review of State-Coun Judgments After Seminole Tribe, 46 UCLA L. REv. 161. 213-28 (1998).

157. A statute authorizing such appeals would be valid, regardless of whether one considered Supreme Court review of a state-court dismissal on sovereign immunity grounds to be an exercise of original or appellate jurisdiction. Although Marbuny v. Madison, 5 U.S. (1 Cranch) 137, 174 (1803), held that the Supreme Court lacks original jurisdiction over suits arising under federal law, a suit against a state properly authorized by Congress pursuant to Section 5 would appear to be within the Supreme Court's original jurisdiction as a suit "in which a State shall be a Party" within the meaning of Article III, Section 2.

158. See supra text accompanying note 154 . On the other hand, the Court elsewhere said that it was "worth mentioning" that Florida statutes authorize "a legislative remedy through a claims bill for payment in full" as well as a judicial remedy. See Florida Prepaid, 119 S. Cr. at 2209 n.9. If the Court here meant to suggest that a damages remedy received through the grace of the legislature would satisfy the remedial requirements of the Due Process Clause, then the statute abrogating sovereign immunity might have to afford the states a reasonable amount of time to consider whether to grant a legislative remedy. Still. Congress would presumably be able to provide a federal forum against states that do not in fact provide an adequate remedy - whether legislatively or judicially - within a reasonable time. Clearly, the mere existence of a mechanism under which a property holder may request a legislative remedy does not satisfy the remedial demands of the Due Process Clause if the legislature fails to provide a remedy. 
individuals of liberty or property, and even if their failure to do so is reviewable by the Supreme Court, the due process regime may differ from the forum-allocation regime in some details. The Supreme Court would have the power to reverse any state court judgment that denied a remedy on sovereign immunity grounds, or that applied a remedial standard that was inadequate as a matter of law. But otherwise, appellate review in the federal courts may be limited. It is possible that errors of fact would be reviewable only under the "some evidence" standard. ${ }^{159}$ As a practical matter, however, this would not represent a dramatic departure from the forumallocation model, as the Supreme Court rarely reviews a case just to correct a factual error.

Of greater concern is the possibility that errors of law would not be reviewable de novo. Perhaps the Court would say that it is empowered to reverse only if the state proceeding violated due process, and that a state proceeding in which a disinterested judge received evidence following fair procedures and conscientiously found the facts and applied the law satisfies due process even if the judge committed legal error. If so, then the "clearly established" standard the Court uses in the officer-liability context may find its way into the due process regime through the back door. ${ }^{160}$ Whether an error of law constitutes a violation of due process is a question that rarely arises, ${ }^{161}$ but the recent decisions cutting back on the availability of habeas relief may suggest a negative answer. ${ }^{162}$ Subjecting Supreme Court review to some variant of the Harlow standard would constitute a marked difference between the due process regime and the forum-allocation regime. But the Court, I think, is more likely to hold that de novo review of questions of federal law is available in the Supreme Court. ${ }^{163}$ If so, then,

159. See Superintendent v. Hill, 472 U.S. 445, 447 (1985); Thompson v. City of Louisvillc. 362 U.S. 199, 206 (1960); see also Gerald Neuman, The Constitutional Requirement of "Some Evidence," 25 SAN DIEGO L. REV. 631 (1988).

160. Presumably, the judge's application of the law would not count as conscientious if it conflicted with clear federal precedent.

161. To be sure, "[t]he Court in Crowell [v. Benson, 285 U.S. 22 (1932),] appeared to assume that Article III, the Due Process Clause, or both required independent judicial decision of questions of law in private rights cases." FALLON ET AL., supra note 132, at 397 . But I am assuming that the state courts have provided an "independent judicial decision." The question is whether the Due Process Clause requires de novo review of such a decision. The Court in Crowell was discussing whether judicial review of the decisions of federal administrative agencies was required, and it read the relevant statutes to guarantee de novo review of questions of law.

162. For example, though the federal habeas statute for state prisoners authorized relief for those "in custody in violation of the Constitution or laws or treaties of the United States," 28 U.S.C. $\$ 2254$ (1994), the Court held in Stone v. Powell, 428 U.S. 465 (1976), that a state conviction could not be challenged on habeas on the basis of legal errors regarding the exclusion of evidence under the Fourth Amendment so long as the state court had offered a "full and fair hearing" on the question. This may suggest that depriving someone of his liberty who has received such a hearing does not violate the Due Process Clause even if legal error was committed.

163. The Court has so far seen fit to apply heightened standards only to the lower federal courts. It seems uninterested in limiting the scope of its own powers. See, e.g., Wilson v. 
subject to the reservations and qualifications stated earlier in this Part, the due process regime for enforcement of federally created property rights against the states would appear to be a substantial resurrection of the forumallocation regime for the enforcement of federal statutory rights against the states.

\section{COLLEGE SAVINGS BANK AND THE NARROWING OF DUE PROCESS}

Though the regime the Court appears to have in mind for property and liberty rights may differ in some details from the forum-allocation regime, it sufficiently resembles it that the Court's decision in Florida Prepaid may fairly be regarded as a partial resurrection of that regime. The resurrection is partial, most importantly because it applies only to state violations of federal obligations that give rise to property or liberty interests within the meaning of the Due Process Clause. In this Part, I consider the meaning of the concept of "property" after the Court's decision this Term in College Savings Bank. I consider specifically whether the right claimed by the plaintiffs in Alden constitutes a property right under the Court's prevailing doctrine. If it does, then the Court in Florida Prepaid either resurrected the forum-allocation view with respect to the very sort of right involved in the case in which the Court purported to reject the same view, or repudiated the understanding of "property" that had prevailed until then.

\section{A. Background}

The Court's attempts to give a precise definition to the terms "liberty" and "property" for purposes of procedural due process are of comparatively recent vintage. ${ }^{164}$ Writing in 1980, John Hart Ely observed that

[u]ntil recently, the general outlines of the law of procedural due process were pretty clear and uncontroversial. The phrase "life, liberty or property" was read as a unit and given an open-ended, functional interpretation, which meant that the government couldn't seriously hurt you without due process of law. What process was "due" varied, naturally enough, with context, in particular with how seriously you were being hurt and what procedures would be

\footnotetext{
Arkansas, 514 U.S. 927 (1995) (demonstrating that the relief unavailable in the lower federal courts under Teague v. Lane, 489 U.S. 288 (1989); and Powell. 428 U.S. 465, is available in the Supreme Court on direct appeal); Griffith v. Kentucky, 479 U.S. 314 (1987); see also South Cent. Bell Tel. Co. v. Alabama, 119 S. Ct. 1180, 1184 (1999) (holding that the Eleventh Amendment does not limit the Supreme Court's appellate jurisdiction).

164. Attempts to define "liberty" for purposes of substantive due process, on the other hand, have been longstanding and controversial. See, e.g., Lochner v. New York. 198 U.S. 45 (1905).
} 
useful and feasible under the circumstances. But if you were seriously hurt by the state you were entitled to due process. ${ }^{165}$

According to Henry Monaghan, the Court in this period read the Due Process Clause to protect "all interests valued by sensible men." 166 The right-privilege distinction limited the scope of substantive due process, and may for a time have limited procedural due process as well, ${ }^{167}$ but the distinction was largely abandoned before the Court decided Goldberg $v$. Kelly, ${ }^{168}$ the case most closely identified with the concept of "new property." Goldberg itself was not a significant departure from the approach described by Ely and Monaghan. ${ }^{169}$ Indeed, all sides conceded that the government's withdrawal of welfare benefits had to comply with due process. ${ }^{170}$ The Court's confirmation that such benefits were property came in a footnote and stressed the importance of such benefits to their recipients. ${ }^{171}$ Goldberg has been described as a "lodestar," 172 and has been blamed (or credited) for the "due process explosion" that followed it. ${ }^{173}$ Its controversial feature, however, was not its conclusion that welfare was property, but rather its decision about the sort of process that was due in welfare cases. As Judge Henry Friendly observed, "After the usual litany that the required hearing 'need not take the form of a judicial or quasijudicial trial,' Mr. Justice Brennan proceeded to demand almost all the elements of one." ${ }^{174}$

The Burger Court subsequently adopted a more flexible balancing test for determining what process is due, ${ }^{175}$ but at the same time, it obviated that

165. JOHN HART ELY, DEMOCRACY AND DISTRUST 19 (1980); see also Timothy P. Terrell. "Property," "Due Process," and the Distinction Between Definition and Theory in Legal Analysis, 70 GEO. L.J. 861, 881 (1982) (" [I]nstead of focusing on the basis for a due process inquiry-the deprivation of some element of the trigger mechanism [i.c., 'life, liberty, or property']-the Supreme Court largely ignored that issue and preoccupied itself almost entirely with the narrow procedural fairness of the administrative process involved.").

166. Henry Paul Monaghan, Of "Liberty" and "Property," 62 CORNELl L. REv. 405, 409 (1977); see also id. at 423 (citing Butler v. Perry, 240 U.S. 328 (1916), for the proposition that the concept of "liberty" embraces "all the interests in personal security ... which had been protected from private interference by the common-law courts"). But cf. Stephen F. Williams, Liberty and Property: The Problem of Government Benefits, 12 J. LEGAL STUD. 3, 20 n.68 (1983) (disputing Monaghan).

167. See William W. Van Alstyne, The Demise of the Right-Privilege Distinction in Constitutional Law, 81 HARV. L. REV. 1439 (1968); Williams, supra note 166, at $20-21$ \& n.68.

168. 397 U.S. 254, 262 n.8 (1970). See generally Van Alstyne, supra note 167.

169. But cf. Williams, supra note 166, at 14-15, 20-21 n.68 (arguing that Goldberg's reliance on the importance of the interest was an innovation).

170. See id. at 14 .

171. See Goldberg, 397 U.S. at 262 n.8 (citing Charles Reich, Individual Rights and Social Welfare: The Emerging Legal Issues, 74 YALE L.J. 1245 (1965); Charles Reich. The New Property, 73 YALE L.J. 733 (1964)).

172. Henry J. Friendly, "Some Kind of Hearing," 123 U. PA. L. REv. 1267, 1299 (1975).

173. Id. at 1268 .

174. Id. at 1299.

175. See Mathews v. Eldridge, 424 U.S. 319, 334-35 (1976). 
issue in many cases by adopting narrower definitions of the concepts that trigger the obligation to afford due process-liberty and property. Having previously found that the deprivation of a government job triggers the Due Process Clause, ${ }^{176}$ the Court in Board of Regents v. Roth held that a government job is a property right only if the employee has a legitimate expectation of continued employment. ${ }^{177}$ The employee's expectation of employment is legitimate if the state's power to terminate the employment is limited by statute or contract. ${ }^{178}$ But someone who holds a job terminable after a year lacks a property interest in the job after the expiration of the year, as he has no "legitimate" expectation to continue to hold the job. ${ }^{179}$ The "entitlement," or "legitimate expectation," standard has largely displaced the test focusing on the importance of the right. ${ }^{180}$ Under this test, a person possesses a property right whenever the law places mandatory obligations on the state for his benefit. ${ }^{181}$

The Court's emphasis on the legitimate expectation resting on statutes or other positive law was taken a step further by then-Justice Rehnquist's plurality opinion in Arnett v. Kennedy ${ }^{182}$ and by the Court in Bishop $v$. Wood. ${ }^{183}$ The latter suggested what the former had expressly adopted, the "bitter with the sweet" theory, under which a putative property right created by statute includes as part of its definition the procedures the statute establishes for its termination. ${ }^{184}$ Under this theory, if state law provides that employees may be terminated only for good cause, but the statute goes on to state that the job may be terminated without notice or a hearing, the latter limitations are regarded as a part of the definition of the employee's property right. In Justice Rehnquist's words, the employee "must take the bitter with the sweet." 185 According to this view, for any property right created by statute, the procedures set forth in the statute would always satisfy due process. Professor Van Alstyne regarded this approach as a major "crack in the new property," 186 even though only a minority of the Court had subscribed to it in Amett. The Court repaired this crack in

176. See Connell v. Higginbotham, 403 U.S. 207, 208 (1971); Slochower v. Board of Higher Educ., 350 U.S. 551, 559 (1956); Wieman v. Updegraff. 344 U.S. 183. 191 (1952).

177. 408 U.S. 564,578 (1972).

178. See, e.g., Cleveland Bd. of Educ. v. Loudermill, 470 U.S. 532. 538-39 (1985): Amett v. Kennedy, 416 U.S. 134, 155 (1974) (Rehnquist, J., plurality opinion).

179. See Roth, 408 U.S. at 578.

180. See Williams, supra note 166 , at 4-5.

181. See Timothy P. Terrell, Causes of Action as Property: Logan v. Zimmerman Brush Co. and the "Government-as-Monopolist" Theory of the Due Process Clause. 31 ExrorY LJ. 491, 499 (1982).

182. 416 U.S. 134 (1974).

183. 426 U.S. 341 (1976).

184. See id. at 153-54 (plurality opinion).

185. Id. at 153 .

186. See William Van Alstyne, Cracks in "The New Propery": Adjudicarive Due Process in the Administrative State, 62 CORNEL L. REV. 445 (1977). 
Cleveland Board of Education v. Loudermill, in which a majority expressly disavowed the "bitter with the sweet" theory, ${ }^{187}$ over Justice Rehnquist's dissent. ${ }^{188}$ The Court held that the Due Process Clause required a distinction between substantive and procedural limitations; only substantive limitations included in the statute creating the right are relevant to whether a property right exists; if one does exist, procedural limitations must satisfy the Due Process Clause. ${ }^{189}$

Until Seminole Tribe, there appeared to be little reason to deny that the Fourteenth Amendment right to due process of law applied to all persons seeking to enforce mandatory legal obligations of the states. In Seminole Tribe, however, the Court held that Congress has the power to abrogate Eleventh Amendment immunity pursuant to the Fourteenth Amendment, but not pursuant to Article I. Under the prevailing definition of property, Congress would potentially have an easy way to circumvent the latter holding: If any mandatory legal obligation imposed by Congress under Article I for the benefit of private individuals were deemed to give rise to a correlative property (or liberty) right under the Due Process Clause, Congress would arguably be able to abrogate sovereign immunity under Section 5 to "enforce" any such obligations. Acceptance of such a power would have effectively gutted Seminole Tribe's holding. ${ }^{190}$ The Court avoided this problem in Florida Prepaid by holding that, even if there is a property right, Congress may abrogate Eleventh Amendment immunity from federal-court jurisdiction only if the states fail to afford a remedy for the deprivation in their own courts. ${ }^{191}$ But the Court's affirmation that the Due Process Clause requires the states to provide a remedy in their own courts, when combined with the "legitimate expectation" test for defining property, threatens to gut the Court's holding in Alden that states are entitled to sovereign immunity in their own courts. This problem would, indeed, have existed even under the narrower test espoused by Justice Rehnquist in Arnett, but later disavowed in Loudermill. The Court in College Savings Bank avoided a total gutting of Alden by embracing an even narrower definition of property. The cost of this partial preservation of

187. 470 U.S. 532,540 (1985) (quoting Arnett v. Kennedy, 416 U.S. 134 (1974)).

188. See id. at 561 (Rehnquist, J., dissenting).

189. See id. at 541 .

190. I have called this problem the "abrogation reductio." Vázquez, supra note 14, at 1744.

191. As discussed above, Chief Justice Rehnquist's opinion also makes it clear that, in the case of a statutorily created property right, the Due Process Clause does not necessarily require all the procedures that the statute gives the property holder. See supra text accompanying notes 182 184. Thus, either he has abandoned the "bitter with the sweet" theory or the theory incorporates procedures into the definition of the property right only when the statute establishes procedures that would otherwise fall short of due process. 
Alden, however, was a corresponding constriction of the basic protections of the Due Process Clause. ${ }^{192}$

The Court's previous efforts to respond to the "due process explosion" by limiting the definition of "liberty" and "property" have not been well received. According to Professor Ely,

What has ensued has been a disaster, in both practical and theoretical terms. Not only has the number of occasions on which one is entitled to any procedural protection at all been steadily constricted, but the Court has made itself look quite silly in the process-drawing distinctions it is flattering to call attenuated, and engaging in ill-disguised premature judgments on the merits of the case before it.... The line of decisions has been subjected to widespread scholarly condemnation, which suggests that sometime within the next thirty years we may be rid of it. ${ }^{193}$

Since those words were written in 1980, the doctrine in this area has taken a significant step in what Professor Ely would presumably consider the right direction with the rejection of the "bitter with the sweet" theory. College Savings Bank, however, suggests that the doctrine will get worse before it gets better. As discussed below, the decision appears to rest on distinctions even sillier than those Ely criticized. Moreover, even the decisions that Ely criticized recognized that "liberty" and "property" are "[g]reat concepts ... purposely left to gather meaning from experience.... [T] hey relate to the whole domain of social and economic fact, and the statesmen who founded this Nation knew too well that only a stagnant society remains unchanged." ${ }^{194}$ This functionalist approach to defining "property" 195

192. There would have been no need to mold a definition of property to accommodate sovereign immunity doctrine if the Court had decided either (1) that the states may not rely on sovereign immunity in their own courts to refuse to provide a remedy to which Congress has subjected them in conformity with the Tenth Amendment, or (2) that, if a remedy is barred by sovereign immunity, then it is not required by the Due Process Clause, even if the state has deprived someone of a property or liberty interest. But the Court rejected the first option in Alden, see supra Part I, and it rejected the second in Florida Prepaid, see supra Part II.

193. ELY, supra note 165, at 19; see also Monaghan, supra note 166 (criticizing the Court's narrowing of liberty and property protected by the Due Process clause): Terrell, supra note 165 (criticizing the Court's method of determining property for due process purposes): Van Alstyne. supra note 186 (criticizing restrictions un new property); Williams, supra note 166 (criticizing the Court's entire new property jurisprudence).

194. Board of Regents v. Roth, 408 U.S. 564,571 (1972) (quoting National Mut. Ins. Co. v. Tidewater Co., 337 U.S. 582, 646 (1949) (Frankfurter, J., dissenting)).

195. Professor Merrill calls this approach to defining property "nominalism." This school of thought "views property as a purely conventional concept with no fixed meaning - an empty vessel that can be filled by each legal system in accordance with its peculiar values and beliefs." Thomas Merrill, Property and the Right To Exclude, 77 NEB. L. REv. 730,737 (1998). Although Professor Merrill is not an adherent of this school, he acknowledges that "[t]oday, the nominalist conception is more-or-less the orthodox understanding of property within the American legal community. Law students have been instructed for years that the bundle of rights metaphor accurately captures the nature of the institution of properny." Id. at 738. 
contrasts with the Court's more limited approach in the takings area, in which it has restricted the concept of property to its more traditional common-law meaning, which takes into account such factors as the alienability of the putative property right. ${ }^{196}$

As discussed below, College Savings Bank appears to reject a functionalist approach in favor of a search for the essence of the concept of property. Just how far the Court has retreated remains uncertain, however. Because the cursory treatment of the issue in College Savings Bank appears to be internally inconsistent, the precise holding that the plaintiff lacked a property right could well be interpreted narrowly in the future or dismissed as a sport. Alternatively, the decision might in retrospect be regarded as an early step in a drastic contraction of the guarantee of procedural due process.

\section{B. College Savings Bank}

The right at issue in College Savings Bank was the right to be free from pecuniary injury resulting from a competitor's false advertising of its own product. Congress prohibited such false advertising in the Lanham Act and gave injured competitors a right to damages from the false advertiser. ${ }^{197}$ Congress made it clear that the prohibition applied to the states, and it expressly abrogated the states' immunity from suit in federal court. ${ }^{198}$ At issue in the case was the validity of this abrogation. As in Florida Prepaid, the plaintiff argued that Congress's abrogation of the states' immunity was "appropriate legislation" under Section 5 because it sought to "enforce" the states' obligations under the Due Process Clause. The Court could easily have struck down the abrogation on the same ground as in Florida Prepaid, as there appears to have been no greater evidence of unremedied false advertising by states than there was of unremedied state patent infringements. By deciding instead that the interests invoked by the plaintiff were not property interests, ${ }^{199}$ the Court established that, unlike states that infringe patents, states that engage in false advertising do not have to provide retrospective relief to those they injure.

Under the "legitimate expectation" test, the right to be free from injuries caused by the state's false advertising of its own product should have qualified as a property right. Certainly, the plaintiff had an expectation that it would not suffer such an injury. Congress had specifically prohibited

196. See Vázquez, supra note 14 , at 1752 \& n.310.

197. See 15 U.S.C. \$1125 (1994).

198. See 15 U.S.C.A. $\$ \S 1122(a), 1125(a)(2)$ (West Supp. 1999).

199. See College Sav. Bank v. Florida Prepaid Postsecondary Educ. Expense Bd., 119 S. Cl. 2219, 2224-25 (1999). 
false advertising, and the validity of this obligation was not in question. ${ }^{200}$ The expectation would appear to have been "legitimate" in the sense that it was backed by a law placing mandatory obligations on the state.

The Court nevertheless found that the right was not property for due process purposes. It stressed that "the hallmark of a protected property interest is the right to exclude others," ${ }^{201}$ and it concluded that the right to be free from false advertising lacks this element. For the "right to exclude" requirement, though, the Court cited a takings case. ${ }^{202}$ The requirement appears to be new to due process jurisprudence, where the Court has said instead that " $[\mathrm{t}]$ he hallmark of property ... is an individual entitlement grounded in ... law, which cannot be removed except "for cause." ${ }^{203}$ As discussed below, the "right to exclude" requirement seems difficult to square with such "new property" rights as the right to receive welfare benefits due in the future or the right to continue to hold a government job. This may suggest a retreat from that line of cases. But the "right to exclude" requirement is also difficult to square with some "old" property rights, including rights that seem indistinguishable from the right invoked by the plaintiff in this very case.

The primary meaning of "exclude" is to bar someone or something from a place. ${ }^{204}$ This sense of the "right to exclude" is easy to apply to rights in real property, but not to other sorts of rights that are clearly "property." For example, the Court in College Savings Bank acknowledged that the Lanham Act's trademark provisions "may well" protect property interests. ${ }^{205}$ In what way do the trademark laws establish a "right to exclude"? A secondary meaning of "exclude" is "to prohibit someone from

200. The obligation imposed on the states would appear to be valid under the standard the Court articulated in New York and Printz-that is, it is an obligation imposed on states as part of a broader class that includes private parties. See supra note 49.

201. College Sav. Bank, 119 S. Ct. at 2224.

202. See Kaiser Aetna v. United States, 444 U.S. 164 (1979).

203. Logan v. Zimmerman Brush Co., 455 U.S. 422, 430 (1982) (citations omitted). Professor Merrill argues that the right to exclude is "the sine qua non" of property. see Merrill. supra note 195, but all of the cases he cites in support of his argument ane takings cases. He concedes that it is "a bit of a stretch" 10 claim that the due process cases are consistent with his view. Id. at 752; see also Leonard Kreynin, Breach of Contract as a Due Process Violation: Can the Constitution Be a Font of Contract Law?, 90 CoLum. L. REV. 1098, 1106 (1990) (noting the different definitions of property for the purposes of the Due Process and Takings Clauses); Vázquez, supra note 14, at 1752 n.310 (same); cf. Eastem Enters. v. Apfel. 524 U.S. 498, 527 (1998) (Breyer, J., dissenting) ("Nor does application of the Due Process Clause automatically trigger the Takings Clause, just because the word 'property' appears in both. That word appears in the midst of different phrases with somewhat different objectives, thereby permitting differences in the way in which the term is interpreted.").

204. See NEW SHORTER OXFORD DICTIONARY 875 definition 1 (5th ed. 1993).

205. College Sav. Bank, 119 S. Ct. at 2224. The Court also conceded that unfair competition amounting to "theft of proprietary information" is the deprivation of a property right. Id. at 2225 . This rests on the tautology that "proprietary information" is property. But it is worth noting that what makes such information proprietary-and thus property-is the fact that the law gives the "owner" of it the right to prohibit others from engaging in certain types of conduct. 
an activity." 206 It is apparently this meaning that the Court had in mind. In acknowledging that some provisions of the Lanham Act may well establish property rights, the Court said that "trademarks ... are the 'property' of the owner because he can exclude others from using them." 207 But the term "exclude," in this sense, is a synonym for "prohibit." ${ }^{208}$ It is unclear why the false-advertising provisions of the Lanham Act do not satisfy this test. Under the Act, the plaintiff clearly had a right to "prohibit" activity on the part of the defendant. The Act itself prohibits false advertising, but the plaintiff had the right to prohibit the defendant's false advertising if such advertising caused the plaintiff injury. ${ }^{209}$ Clearly, this injury sufficed to give the plaintiff standing to obtain injunctive relief to stop any such false advertising, and the Eleventh Amendment does not preclude such relief in a suit against state officials. ${ }^{210}$ Thus, the false-advertising provisions of the Lanham Act cannot be distinguished from the trademark provisions on the ground that the latter include a "right to prohibit" whereas the former do not. ${ }^{211}$

Nor can the rights reflected in the Lanham Act's false-advertising provisions be distinguished on this ground from other intellectual property rights that the Court has found to be "property." The Court in Florida Prepaid recognized that a state deprives a patentholder of property when it intentionally infringes the patent. But a state that infringes does not deprive

206. NEW SHORTER OXFORD DICTIONARY, supra note 204, at 875 definition 2.

207. College Sav. Bank, 119 S. Ct. at 2224.

208. Similarly, Professor Merrill, who defends the centrality of the right to exclude to the concept of property, argues that someone who owns a copyright in a song has a right to exclude because he "can exclude others from performing or copying [the song]." Merrill, supra note 195. at 741 n.38. Again, a more apt word would have been "prohibit."

209. Surely the Court does not mean that the plaintiff lacks a right to prohibit false advertising, because the statute itself prohibits such conduct. It is true that the heading of the pertinent section reads, "False designations of origin and false descriptions forbidden," 15 U.S.C. $\S 1125$ (1994), but it is noteworthy that the text of the section does nothing more than create a private right of action for injunctive relief and damages in favor of persons injured by such advertising.

210. See Ex parte Young, 209 U.S. 123 (1908). On one view, a property rule differs from a liability rule in that the former is enforceable through an action for an injunction, whereas the latter is enforceable only in an action for damages. See Guido Calabresi \& Douglas Melamed. Property Rules, Liability Rules, and Inalienability: One View of the Cathedral, 85 HARV. L. REV. $1089,1105-15$ (1972). Under this test, in the light of Ex parte Young and $\$ 1983$, an individual would possess a property right against a state unless the statute imposing the obligation affirmatively denies an action for injunctive relief against an officer.

211. It is perhaps awkward to say of the false-advertising plaintiff what the Court in College Savings Bank said of the trademark owner: that "he can [prohibit] others from using" the putative property. College Sav. Bank, $119 \mathrm{~S}$. Ct. at 2224 (emphasis added). If so, it is because of a deficiency in our language, not a deficiency in the former's rights as compared to the latter. Although we say that $A$ has a right to prohibit $B$ from "using" $A$ 's trademark, $B$ does not "use" $A$ 's trademark in the same way he might use, say, $A$ 's automobile. "Use" of the trademark consists in creating another manifestation of the symbol and affixing it to a product. Such use is thus at bottom merely the performance of acts prohibited (or made tortious) by the law. $C$ similarly has a right to prohibit $B$ from "using" false statements exaggerating the quality of $B$ 's competing products or maligning the quality of $C$ "s products. 
the patentholder of his patent, or even of the rights reflected in the patent (namely, the right to prohibit competitors from employing a specified technique). The patentholder possesses his patent and his right after the state's infringement, just as he did before. What the infringement deprives the patentholder of are the profits he expected to earn as a resuit of the monopoly to which the patent entitled him..$^{212}$ Expected profits, however, are precisely what a Lanham Act plaintiff claims he was deprived of by a state's false advertising in violation of the Lanham Act. ${ }^{213}$ The Court has also found trade secrets- "one of the weakest forms of intellectual property" 214 - to be "property" for purposes of the Takings Clause. ${ }^{215}$ "[T]o be the owner of a trade secret means only that one can recover tortlike remedies for a breach of promise and contract or unjust enrichment-like remedies for a tort." ${ }^{216}$ Much the same can be said of the right to be free from false advertising. ${ }^{217}$

It is even more difficult to see how other, seemingly uncontroversial sorts of property rights involve a "right to prohibit others from using"

212. See Livesay Window Co. v. Livesay Indus., 251 F.2d 469, 471 (5th Cir. 1958).

213. The Court in College Savings Bank suggested at one point that the plaintiff's problem was not that it lacked property, but that the state did not deprive him of it. See College Sav. Bank, $119 \mathrm{~S}$. C. at 2225 (" $[\mathrm{N}]$ ot everything which protects property interests is designed to remedy or prevent deprivations of those property interests."). This suggests that the Court was relying on past cases that seemed to indicate that the Due Process Clause is implicated only when the deprivation is caused directly by the state, rather than indirectly. See Terrell. supra note 165, at 919-20 (discussing Martinez v. California, 444 U.S. 277 (1980)). If the Coun was suggesting that the state did not directly cause the plaintiff's loss of expected profits because the loss depended on the intervening decisions of clients, the argument would appear to apply equally to the patentholder's claim of infringement by the state. In any event, the cases that suggest a distinction between direct and indirect causation are best read to incorporate a proximate-cause standard. See id. The Lanham Act entitles a plaintiff to compensation only for injuries proximately caused by the false advertiser's actions.

214. Heald \& Wells, supra note 144 , at 856.

215. See Ruckelshaus v. Monsanto, 467 U.S. 986, 1002-04 (1984).

216. Heald \& Wells, supra note 144 , at 860 .

217. Professor Merrill argues that his insistence that the right to exclude is the sine qua non of property can accommodate the status as property of "some of the most quintessential interests of the modem capitalist state-bank accounts, bonds, commercial paper, common stock, and the like," which he also describes as "choses in action." Merrill, supra note 195, at 750-51. His explanation shows that he understands the "right to exclude" to exist whenever the law protects the putative property interest through tor-like remedies:

The only value reflected in these interests [i.e., bank accounts, bonds, and stocks] is their exchange value.... And their exchange value is fully protected by the law against interference by others. These interests are protected by criminal nules against theft and by civil actions for misappropriation, fraud, etc. These legal rules function in a manner directly parallel to the laws against trespass that protect land and the actions for theft and replevin that protect chattels. In effect, therefore, the law of theft (together with its cognate civil actions) gives the holders of interests in choses in action the right to exclude others from interfering with the exchange value of these interests, and that is all one needs to give them the status of property.

Id. at 751. The Lanham Act does not impose criminal penalties for false adverising, but if provision for such penalties were regarded as necessary to give people a right to compensation from the state, Congress could easily add them. 
something. ${ }^{218}$ For example, the Court noted in College Savings Bank that "[t]he assets of a business (including its goodwill) unquestionably are property." ${ }^{219}$ Certainly, a business's tables and chairs satisfy the "right to exclude" test, as others can be prohibited from using them. But is it fair to say that a person can be prohibited from "using" another's goodwill? To be sure, one way $A$ can deprive $B$ of $B$ 's goodwill is to try to pass itself off as $B$, perhaps by using its trademark. In this respect, the right to goodwill seems identical to the right to a trademark. But $A$ can also deprive $B$ of goodwill by making false statements about $B$. At oral argument, Justice Scalia appeared willing to grant that $A$ deprives $B$ of a property right when it does this. ${ }^{220}$ It seems clear that $A$ also deprives $B$ of goodwill if the two are competitors and $A$ makes false statements exaggerating its own product's quality. A false statement exaggerating the quality of one product can be expected to diminish the market for directly competing products. That is why the statement is made. Moreover, this is the only circumstance in which $B$ would have a cause of action against $A$. The cases confirm that $A$ deprives $B$ of goodwill when it makes false claims about its own product that succeed in diminishing the demand for $B$ 's product or services. ${ }^{221}$

218. Much of the difficulty in describing the interest protected by the Lanham Act in terms of a "right to exclude" lies in the lack of a term for the "thing" from which the "owner" of that right is excluding others. For this reason, one might object that these interests are not "property" because they "are not discrete 'things' at all." Terrell, supra note 181, at 514 ; see also id. at 514 n.90 ("The necessity for a 'thing' of some sort is of course critical not only to the central case of private property or ownership, but to any of the cases in the property set. Without it, one of the necessary dimensions of the concept is missing."). But, again, the deficiency seems to be one of language, not of rights. In the case of all rights in intellectual property, perhaps all intangible property rights, the "thing" that is regarded as property is "some ideational abstraction or other." J.W. HARRIS, PROPERTY AND JUSTICE 45 (1996). In some cases, we have a word for the abstraction that provides the object for a sentence taking the form " $X$ has a right to exclude [or prohibit] others from using ...." That there is no similar word for the right protected by the falseadvertising provisions of the Lanham Act should not obscure the fact that the plaintiffs rights under those provisions are analytically the same as his rights under provisions that do supply a word for the abstraction.

219. College Sav. Bank v. Florida Prepaid Postsecondary Educ. Expense Bd., $119 \mathrm{~S}$. Ct. 2219,2225 (1999). Though the Court did not cite any authority for this concession, it could have cited many cases, including Kimball Laundry Co. v. United States, 338 U.S. 1. 13 (1949). Authorities are collected in $1 \mathrm{~J}$. THOMAS MCCARTHY, MCCARTHY ON TRADEMARKS AND UNFAIR COMPETITION $\S 2: 20$, at 2-41 n. 1 (4th ed. 1996); Floyd A. Wright. The Nature and Basis of Legal Goodwill, 24 ILL. L. REV. 20, 21 \& n.4 (1929) ("[T]here has been a considerable degree of uniformity in treating goodwill as property."). But cf. Paul v. Davis, 424 U.S. 693. 712 (1976) (finding that injury to reputation does not implicate a property or liberty interest). Paul is discussed infra note 256.

220. See United States Supreme Court Official Transcript, College Sav. Bank (No. 98-149). available in 1999 WL 252691 , at *7.

221. See, e.g., Alpo Petfoods v. Ralston Purina Co., 913 F.2d 958, 960, 969 (D.C. Cir. 1990) (Thomas, J.). Indeed, before it was amended in 1988, the Lanham Act gave $A$ a cause of action against $B$ for false advertising only if $B$ exaggerated the qualities of its own products, Icaving it to the common law to protect $A$ from $B$ 's false statements about $A$ 's products. Yet during this period it was well established that harm to goodwill was one of the measures of damages availablc to $A$. See U.S. Healthcare v. Blue Cross, 898 F.2d 914, 921-23 (3d Cir. 1990). 
That, of course, was precisely the property right that the plaintiff was claiming in College Savings Bank, yet the Court found that the plaintiff lacked a property interest. The Court distinguished the "assets of a business (including its good will)" from "the activity' of doing business, or the activity of making a profit." ${ }^{222}$ "The latter, the Court said, were the only things of the plaintiff's upon which the defendant's false advertising "impinged," 223 and those activities, the Court said, are "not property in the ordinary sense." ${ }^{224}$ But the Court appears to have drawn a false dichotomy. The false advertising "impinged" upon the plaintiff's "activity of making a profit," but it also impinged upon its goodwill, which is a pecuniary interest whose measure is the present value of the expected profits that the plaintiff's good name could be expected to generate in the future. ${ }^{25}$

The Court in College Savings Bank considered and appeared to reject the argument that "all civil rights of a pecuniary nature are property rights." 226 It interpreted the statement in International News Service that "equity treats any civil right of a pecuniary nature as a property right" 227 as a statement about a quirk of equity jurisprudence: Equity "treats" such rights as property rights even though they really are not. In the end, though, the Court conceded that the pecuniary right involved in International News Service was indeed a property right. It thus left us without an example of a pecuniary right that is not a property right, other than the right the plaintiff claimed in College Savings Bank. Since, as we have seen, the reasons the Court offered for distinguishing this right from conceded property rights are unpersuasive, we are left to search for other possible distinctions.

The defendant's conduct was alleged to have "impinged" upon the plaintiff's expected profits. Profits are money, and money is quintessential property. A persuasive distinction would thus isolate the factors that distinguish such lost profits from money in the bank. Perhaps the key difference is that lost profits are by definition money that the plaintiff does not possess. Does lack of possession explain why the plaintiff lacked property?

The Court's decision last Term in American Manufacturers Mutual Insurance Co. v. Sullivan ${ }^{228}$ suggests that possession may be important. The relevant state law in that case entitled plaintiffs to compensation for

222. College Sav. Bank, 119 S. Ct. at 2225.

223. Id.

224. Id

225. See generally Kimball Laundry Co. v. United States, 338 U.S. 1. 17 \& n.9 (1949): Standard Oil Co. v. Moore, 251 F.2d 188, 219 (9th Cir. 1957); I MCCARThY, supra note 219, $\S \S 2: 17,2: 21$; Note, An Inquiry into the Nature of Goodwill. 53 CoLUM. L. REV. 660, 677-82 (1953).

226. College Sav. Bank, 119 S. Ct. at 2225.

227. Id. (quoting International News Serv. v. Associaled Press. 248 U.S. 215. 236 (1918)).

228. 119 S. Ct. 977 (1999). 
"reasonable" medical expenses, but it went on to provide that if the insurer disputed the reasonableness of the expense, the matter would be submitted to an impartial tribunal and the insurer would not have to pay until the tribunal determined that the expense was reasonable. The plaintiffs argued that the procedure did not afford them due process, but the Court held that the procedure did not deprive the plaintiffs of a property right. In its opinion, the Court emphasized that the plaintiffs' right to receive payment from the defendants would "attach" only after the plaintiffs cleared the procedural hurdles set forth in the statute. The Court distinguished Goldberg v. Kelly and Mathews v. Eldridge-cases in which the Court had held that an individual had a property right to receive a future stream of welfare payments-on the ground that "[i]n both cases, an individual's entitlement to benefits had been established, and the question presented was whether predeprivation notice and a hearing were required before the individual's interest in continued payment of benefits could be terminated." ${ }^{229}$ Does this suggest that the Due Process Clause protects persons against state action that takes away something the person already possesses, but not against state action that denies them something they do not possess?

A closer look at American Manufacturers shows that the Court did not so hold. First, the benefits claimed by the plaintiffs in Goldberg and Mathews were not in their possession; indeed, they were not even yet due and payable to them. If the plaintiffs had been litigating about past-due benefits, the suit would have been dismissed on Eleventh Amendment grounds. ${ }^{230}$ What the plaintiffs did possess was an administrative or judicial decision "establishing" that they had been eligible for such benefits in the past. The state claimed that they were no longer eligible, and the Court held that it could terminate future payments only after a hearing. Despite the Court's emphasis in American Manufacturers that the right to benefits had already been "established" in Goldberg and Mathews, the Court did not hold that someone who claims to be eligible for benefits under the law but does not yet possess an administrative or judicial determination of eligibility lacks a property right. If it had, its holding would have contradicted clear precedent. As already noted, it is well established that a cause of action is a property right. ${ }^{231}$ The reason is not hard to perceive. If a cause of action were not a property right until the claimant's entitlement to damages had been judicially "established," a plaintiff would not be entitled to due process of law until after he had won his case. A judge who decided a case against a plaintiff by the flip of a coin, or pursuant to a stated policy

229. Id. at 990.

230. See Edelman v. Jordan, 415 U.S. 651 (1974).

231. See cases cited supra note 91. 
of always ruling for the defendant, would be violating no constitutionally guaranteed right to due process. That would be absurd. It is commonly, and rightly, understood that plaintiffs are entitled to due process at trial. ${ }^{232}$

That American Manufacturers does not hold otherwise is confirmed by a footnote stating that "[r]espondents do not contend that they have a property interest in their claims for payment, as distinct from the payments themselves." 233 Had the respondents relied on their claim to payment as their property right, they would presumably have lost on the ground that the state does not "deprive" a person of a claim until the proceedings to determine the merits of the claim are concluded. ${ }^{234}$ The Courn's holding that postponing the payment until the end of the proceeding does not violate due process was thus fully consistent with the principle that the Due Process Clause ordinarily requires a predeprivation hearing. ${ }^{235}$ But that is not to say that no property right existed before the end of the proceeding. The claimant possessed a property right in the claim, and that is why he was entitled to a hearing and fair procedures to claim the money, as Justice Ginsburg emphasized in her concurrence. ${ }^{236}$ Similarly, someone with an asyet-unestablished claim to welfare benefits, like any other plaintiff, should be entitled to a hearing and the fair procedures guaranteed by the Due Process Clause to establish her eligibility for such benefits. ${ }^{277}$ She is just not entitled to get the money before her eligibility has been determined. ${ }^{235}$

American Manufacturers thus indicates that the money College Savings Bank expected to make in the future was not yet its property. But the case is consistent with the idea that College Savings Bank possessed a property right in its expectation that it would make such money in the future free of

232. See, e.g., Logan v. Zimmerman Brush Co., 455 U.S. 422, 429 (1982) ("The Court traditionally has held that the Due Process Clauses protect civil litigants who seek recourse in the courts, either as defendants hoping to protect their property or as plaintiffs attempting to redress grievances." (citing Societé Internationale v. Rogers, 357 U.S. 197 (1958); Hammond Packing Co. v. Arkansas, 212 U.S. 322, 349-51 (1909); Hovey v. Elliott, 167 U.S. 409 (1897); Windsor v. McVeigh, 93 U.S. 274 (1876))).

233. American Mfrs., 119 S. C. at 990 n.13. The concurring opinion of Justice Breyer, joined by Justice Souter, emphasized this concession. See id. at 991 (Breycr. J., concurring in part).

234. The "state" defendants in American Manufacturers were local govermment officials, whose actions are state action for Fourteenth Amendment purposes but not for Eleventh Amendment purposes. See Vázquez, supra note 14, at 1704 n.100. The plaintiffs thus would not have lost on the ground (discussed furher below) that, in the light of Seminole Tribe and Alden, individuals have no right of action for retrospective monetary relief against the state.

235. On the latter principle, see, for example, Zinermon v. Burch. 494 U.S. 113 (1989), which holds that predeprivation procedural safeguards should normally be required before an involuntary confinement of a mental patient.

236. See American Mfrs., 119 S. Ct. at 991 (Ginsburg, J., concurring in part).

237. But cf. id. at 990-91 n.13 (reserving the question and citing Lyng v. Payne, 476 U.S. 926. 942 (1986); and Walters v. National Ass'n of Radiation Survivors, 473 U.S. 305, 320 n.8 (1985)).

238. Goldberg's holding that someone who has previously been found eligible for such benefits is entitled by the Due Process Clause to a hearing before the stream of benefits is terminated is discussed further infra Section III.C. 
false advertising by competitors, even state competitors. ${ }^{239}$ Indeed, as already noted, "goodwill" - which the Court said was "unquestionably" property-is the term we use to describe that stream of future profits, just as "chose in action" is the term we use to describe a plaintiff's right to receive money from the defendant if he prevails in litigation. ${ }^{240}$ Its status as property is not vitiated by the fact that the plaintiff does not yet possess the money or the fact that the right to it has not yet been reduced to judgment or otherwise "established." 241

The Court in College Savings Bank appears to have believed that $B$ deprives $A$ of property when $B$ makes false statements about $A$ 's product, but not when $B$ makes false statements about $B$ 's. If so, the Court's distinction does not have to do with "what" the defendant deprived the plaintiff of (in both cases it is future profits), but turns instead on more abstract features of the defendant's obligation towards the plaintiff, and the plaintiff's correlative right vis-à-vis the defendant. A distinction between the obligation not to make false statements about one's own products and the obligation not to make false statements about those of one's competitors may find some support in traditional conceptions of property. A traditional attribute of property-one that is, indeed, closely associated with, and perhaps traceable to, the right to exclude-is that the owner can give it away or (what may be the same thing) license its use. ${ }^{242}$ One can say that $A$ has the right to license $B$ to malign $A$ 's product (that is, by failing to bring a lawsuit, or perhaps by agreeing in advance not to do so), but it is more difficult to say that $A$ has the right to license $B$ to exaggerate the quality of $B$ 's product; under the law, all competitors injured by such misrepresentations have a cause of action against $B$. The Court suggested that was this was the basis of its holding when it stated, echoing Blackstone ${ }^{243}$ that the false-advertising provisions of the Lanham Act did not confer on the petitioner any right over which it had "exclusive dominion." The Court may have meant that the petitioner lacked "exclusive dominion" over the right to prevent Florida Prepaid from

239. As noted earlier, there is no question that the state is prohibited from engaging in false advertising. See supra text accompanying note 198.

240. Because the essence of the latter property right is a right to make a claim in litigation. the state does not deprive a plaintiff of a chose in action until the end of the proceeding. A state that falsely advertises and injures the goodwill of a competitor, on the other hand, would appear to deprive the competitor of his property at the time the false advertising has its intended effect.

241. Nor is its claim to being property undermined by the fact that its value depends on predictions about future events. The value of real estate taken by the state similarly depends on predictions about the future, yet real estate is unquestionably property.

242. See J.E. PENNER, THE IDEA OF PROPERTY IN LAW $80-97$ (1997) (discussing the right to abandon, transfer, and give away property, and their relation to the right to exclude); Merrill. supra note 195 , at $743 \&$ n. 43 (same).

243. See 2 BLACKSTONE, supra note 89 , at *2 (famously defining property as "that sole and despotic dominion which one man claims and exercises over the external things of this world, in total exclusion of the right of any other individual in the universe"). 
exaggerating the quality of its own product because all competitors who may be injured by any act of false advertising shared the right to preclude such conduct.

If so, then the Court may have embraced a definition of "property" that denies such status to interests that can only be injured through conduct that also injures an indeterminate number of others (here, the interest in being free from pecuniary injuries resulting from someone else's false statements about his own products). ${ }^{244}$ Denying individual relief for such widespread injuries would be consistent with the Court's reference to the principle res publica, res nullius, ${ }^{245}$ and it would accord with views that Justice Scalia has expressed in other contexts. ${ }^{246}$ But this refined "exclusive dominion" test is hard to defend by reference to any relevant policies, ${ }^{247}$ and it would be difficult to apply. ${ }^{248}$ The test also fails to support the Court's conclusions. It might be plausible to say that the plaintiff in College

244. I have formulated the definition this way in order to accommodate such cases as a government's decision to flood a large area of land. Such action is clearly a tuking of property even though the conduct injures a large number of persons. It satisfies the posited definition because the interest that constitutes the property can be (although it was not here) injured through conduct that does not also injure an indeterminate number of others.

245. See College Sav. Bank v. Florida Prepaid Postsecondary Educ. Expense Bd., $119 \mathrm{~S}$. Ct. 2219,2224 (1999) (recognizing that "the right that we all possess to use the public lands is not the 'property' right of anyone").

246. See Lujan v. Defenders of Wildlife, 504 U.S. 555 (1992); Antonin Scalia, The Doctrine of Standing as an Element of the Separation of Powers, 17 SUFFOLK U. L. REV. 881, 894-97 (1983). Although there is language in Lujan suggesting that an individual cannot suc to protect the "public" interest, see Lujan, 504 U.S. at 576 ("Vindicating the public intcrest . . is the function of Congress and the Chief Executive."), the actual holding allows such suits if the plaintiff can show that she suffered a particularized injury, see id. at 579 (Kennedy. J., concuring in pant and concurring in the judgment) (indicating that the plaintiffs would have had standing had they purchased airplane tickets).

247. Cf. United States v. Students Challenging Regulatory Agency Procedures (SCRAP), 412 U.S. 669,688 (1973) ("To deny standing to persons who are in fact injured simply because many others are also injured, would mean that the most injurious and widespread Govemment actions could be questioned by nobody. We cannot accept that conclusion."). This aspect of the rule might perhaps be said to advance the policy, sometimes ascribed to sovereign immunity law, of protecting state treasuries. See Alden v. Maine, $119 \mathrm{~S}$. Ct. 2240, 2250 (1999). The broader the class of injured people, the greater the threat to state treasuries. This is unconvincing, however, as the executive branch remains available to seek compensation, and perhaps even punitive relief, for widespread injury. A more plausible defense of the rule would be that individual retrospective relief is less necessary in the case of widespread injury because the executive is more likely to sue to enforce such obligations. See Vázquez, supra note 3. Professor Jackson has suggesied that the rule permitting prospective but not retrospective relief, even though prospective relief is just as costly (perhaps more so), may be justified on the ground that prospective relief is likely to benefit society in general, whereas retrospective relief benefits only discrete people, whose interests may well be adverse to that of the general public. See Jackson, supra note 19, at 91 . This analysis would suggest that compensation should be available in precisely those cases in which the interpretation of "property" discussed in the text would make it unavailable to individuals (that is, when the injury caused by the state's unlawful action is widespread).

248. The Court's attempts to draw similar lines in the context of standing have resulted in a doctrine that is widely regarded as incoherent. See Steven L. Winter, The Metaphor of Standing and the Problem of Self-Governance, 40 STAN. L. REV. 1371, 1372-73 (1988) (citing judicial and scholarly authority for the proposition that standing doctrine is incoherent). 
Savings Bank lacked exclusive dominion over the defendant's obligation not to make false statements about its own products, but it is less clear that the plaintiff lacked exclusive dominion over its right to be free of injury as a result of such conduct. Such individuated injury, when it occurs, is normally enough to confer standing, even if many others have been similarly harmed. Moreover, the cause of action for damages that results when such injury occurs is regarded as a property right. While it is true that Alden holds that individuals do not have a cause of action for damages against states who violate duties imposed pursuant to Article I, Florida Prepaid shows that the absence of such a cause of action does not negate the existence of a property right. College Savings Bank itself recognizes that goodwill is property, and, as already discussed, the plaintiff was alleging an injury to its goodwill (defined as a legitimate expectation of future profits). In short, the conclusion that the plaintiff lacked exclusive dominion over the defendant's conduct fails to explain why the plaintiff was not suing to protect a property right, or why the Lanham Act does not "remedy or prevent deprivations of ... property interests." 249

In any event, if this is the line drawn by College Savings Bank, the definition of property would remain relatively broad, and hence Florida Prepaid would mean that Alden's holding was of narrower significance than it appeared to be. Consider the Court's recent decision in Kimel $v$. Board of Regents ${ }^{250}$ striking down the abrogation of state sovereign immunity in the Age Discrimination in Employment Act (ADEA). ${ }^{251}$ The ADEA prohibits age discrimination with respect to employment, and it applies to the state as employer. If government jobs are property to the extent that the law places mandatory limits on the employer's discretion, ${ }^{252}$ then someone who is fired from such a job or otherwise injured in violation of the ADEA would seem to have a due process right to compensatory relief. ${ }^{253}$ The job-and even the more abstract right to be free from discrimination-would appear to be property under the "exclusive dominion" test. The same would be true of the rights to accrued wages claimed by the employees in Alden, ${ }^{254}$ and indeed of the rights created by

249. College Savings Bank, 119 S. Ct. at 2225; see also supra note 213.

250. 120 S. Ct. 631 (2000).

251. 29 U.S.C.A. \$\$ 621-634 (West Supp. 1999).

252. See supra notes 176-179 and accompanying text.

253. Someone subjected to unlawful discrimination in the hiring process might have a more tenuous claim to a property right in the job. If she can show that she would have gotten the job but for the unlawful discrimination, however, it seems difficult to distinguish her expectation of a job from a business's expectation of future profits. Moreover, she would appear to have exclusive dominion over the defendant's obligation not to discriminate against her. But cf. infra note 254 (discussing the government's power to enforce this obligation without the employee's consent).

254. There is one feature of the FLSA and of the federal laws prohibiting discrimination in employment that may require the conclusion that their violation does not constitute a deprivation of property under the test discussed in the text. The FLSA gives the Secretary of Labor the power to maintain an action against the employer without prior written request of the employec. See 
many, perhaps most, congressional statutes that establish a right of action for damages. ${ }^{255}$

In short, if College Savings Bank holds that the right involved in the case was not "property" because it could be violated only through conduct that similarly injured an indeterminate number of others, then it does not narrow the scope of the Due Process Clause significantly. Indeed, the Court's recognition that goodwill is "unquestionably" property may broaden it a bit. ${ }^{256}$ On the other hand, the test would be difficult to apply in many contexts, and it would produce anomalous results. Although Justice Scalia may well have had this rule in mind, it is far from clear that all of the members of the majority would embrace such a test. ${ }^{257}$

Donovan v. Brown Equip. \& Serv. Tools, 666 F.2d 148, 156 \& n.10 (5th Cir. 1982). Similarly, under the federal antidiscrimination laws, the Equal Employment Opportunity Commission may bring an action against an employer even if the employee does not consent. See 42 U.S.C. $\S 2000 \mathrm{e}-5$ (1994). Thus, in neither case does the employee have the ability to license the employer to violate the law. This illustrates another anomaly about the proposed test: A provision designed to make the stante more effective in protecting the interests of the employees has the effect of denying the relevant rights the status of property, and hence of limiting the employec's rights when the employer is the state. For this reason, the posited test scems implausible to the extent that it would deny an employee's right the status of property on the ground that the government has been given the power to enforce it. It seems more sensible to assimilate the govemment's power in such circumstances to a guardian's power to defend the property of a child in cour. In any event, if this were the only reason violations of these laws did not deprive employees of property, Congress could cure the problem by amending the statute to provide that the relevant agencies may bring actions under these laws against the states only if the relevant employees consent. An earlier version of the FLSA allowed the Secretary of Labor to bring suit only "when requested by [the affected employees] to do so." Donovan, 666 F.2d at 156.

255. An exception might be the Americans with Disabilities Act, 42 U.S.C. $\$ \$ 12101-12213$ (1994), which imposes some obligations on states the violation of which would affect an indeterminate number of persons with disabilities.

256. Before College Savings Bank, some lower cours had ruled, in reliance on Paul v. Davis, 424 U.S. 693 (1976), that goodwill is not a property right. See WMX Techs. v. Miller. 197 F.3d 367, 374-75 (9th Cir. 1999) (finding that allowing recovery for loss of goodwill is "contrary to the basic thrust of Paul v. Davis"); Cypress Ins. Co. v. Clark, 144 F.3d 1435, 1436 (1 lth Cir. 1998) (stating that an allegation of a loss of goodwill "must be accompanied by a constitutionally recognized injury"). The Court in Paul held that a person's reputation is not by itself property, see Paul, 424 U.S. at 701, and the lower courts have equated goodwill with reputation. Paul has of course been severely criticized, see, e.g., ELY, supra note 165, at 19 \& n.31; Jeffrics, supra note 134, at 78-79; Monaghan, supra note 166, at 423-29, and for good reason. Justice Scalia's statement that goodwill is "unquestionably" property (and apparently self-evidently as well, as the Court cited no authority) shows just how counterintuitive the Paul holding was, and may signal a rejection of that much criticized decision. Altematively. Paul could be squared with College Savings Bank if interpreted narrowly as a holding that noneconomic injury to reputation is not property. Goodwill, by contrast, reflects the economic value of reputation. Such an interpretation derives support from the Court's description of Davis's claimed injury as purely stigmatic. See Paul, 424 U.S. at 711-12. Additionally, the Cour in Paul emphasized that there was no law that "extend[ed] to the respondent any legal guarantec of present enjoyment of reputation." Id. at 711. By contrast, there is a law, the Lanham Act, that guaranteed College Savings Bank freedom from economic injury resulting from the state's false advertising.

257. For example, Justice Kennedy was unwilling to go entirely along with Justice Scalia's similar analysis in Lujan. See Lujan v. Defenders of Wildlife, 504 U.S. 555, 579-80 (1992) (Kennedy, J., concurring in part and concurring in the judgment). 
While the Court's specific holding-that the plaintiff in College Savings Bank did not possess a property interest that was infringed by the state-raises more questions than it answers and thus may be of limited precedential value, there is a strong indication in the opinion of a basic change in the Court's approach to defining property, and the Court's new approach bodes ill for the Court's "new property" jurisprudence. As noted, the Court's earlier cases emphasized that the concepts of liberty and property are broad and majestic and "gather meaning from experience." 258 Cases such as Goldberg $v$. Kelly appeared to reflect a conscious decision to treat certain rights as property rights for purposes of the Due Process Clause, even though they had not before been regarded as such. ${ }^{259}$ In College Savings Bank, however, as already noted, the Court distinguished a prior case that had indicated that "equity treats any civil right of a pecuniary nature as a property right" as a statement that equity treats them as property rights even though they are not really such. ${ }^{260}$ The Court's indication that something either is or is not really a property right, when accompanied by its importation of Takings Clause standards into the due process inquiry, suggests a drastic narrowing of the scope of the Due Process Clause. It suggests that the Court may be poised to reject the cases, such as Goldberg, in which it decided to treat certain rights as property rights even though, from a historical perspective, they properly were not.

\section{Alden and the Right to Accrued Wages}

A comparison of the right involved in Alden with the right involved in Goldberg shows either that, under the holding of Florida Prepaid, the Alden plaintiffs would have been entitled under the Due Process Clause to the relief the Court in Alden denied them, or that the Court now rejects its "new property" jurisprudence. ${ }^{261}$ The law provided that persons who

258. National Mut. Ins. Co. v. Tidewater Ins. Co., 337 U.S. 582, 646 (1949) (Frankfurter, J., dissenting); see also supra note 194 and accompanying text.

259. See Merrill, supra note 195, at 752 ("Goldberg and its progeny are clearly decisions designed to expand the scope of due process protection for instrumental ends.").

260. See supra notes 226-227 and accompanying text.

261. Professor Woolhandler finds the conflict between the Court's approach to defining property in College Savings Bank and the "new property" cases so manifest that she interprets last Term's cases as adopting a distinction between "old property" and "new property." See Woolhandler, supra note 3. For "old" property, she argues. Florida Prepaid establishes that the states are required to provide a retroactive remedy, whereas for "new" property such as was involved in College Savings Bank, the states are required to provide fair procedures but not a backward-looking remedy. See id. This would certainly be a way to avoid the most disturbing implications of College Savings Bank. But the Court did not purport to be drawing a line between old and new property. Rather, it held that the bank did not have a property right for purposes of the Due Process Clause. It is thus difficult to interpret the decision as preserving some procedural protections in suits involving new property. If it had meant to say instead that the Due Process Clause requires less process in cases involving false advertising, it could have struck down the abrogation of sovereign immunity in the Lanham Act on the same ground that it struck down the 
performed work under certain conditions were entitled to a certain level of payment. The plaintiffs had performed the work and were seeking the payment. Was their right to accrued wages a property interest? They appear to have had a legitimate expectation that they would be paid such amounts if they performed the work. Indeed, if they had sought an injunction on an Ex parte Young theory or under $\S 1983$, the Eleventh Amendment would have been no bar. ${ }^{262}$ If their employer had been a private company, they would have had a claim against the employer for the past-due wages, and such a claim, as we have seen, would be a property right under existing case law. Because their employer was the state, they had no cause of action, as Alden itself holds. But Florida Prepaid indicates that, notwithstanding sovereign immunity, the state must afford a remedy for illegal deprivations of property, and the case establishes that a property right may exist against

abrogation in the patent law. Moreover, as discussed above. it is difficult to distinguish the interest of which the petitioner was deprived in College Savings Bank from the interest involved in Florida Prepaid. It is thus hard to see why the former falls in the "new propeny" category, while the latter is "old property." See Jackson, Principle and Compromise, supra note 3.

The attitude toward the new property cases of the members of the Court's Eleventh Amendment majority is illustrated by a recent exchange at an oral argument. In response to a lawyer's invocation of Logan v. Zimmerman Brush Co., 455 U.S. 422 (1982). Chief Justice Rehnquist quipped that Logan was "way out on the margin." The lawyer promptly agreed and withdrew his reliance on the case. United States Supreme Court Official Transcript. United States v. Martinez-Salazar (submitted Nov, 29, 1999) (No. 98-1255), available in 1999 VVL 1134649, at *42; see also U.S. Supreme Court Official Transcript. Baker v. General Motors Co.. 522 U.S. 222 (1998) (No. 96-653), available in 1997 WL 638425, at *16 ("I don't think you'll find much disposition on the Court to enlarge Logan v. Zimmerman.").

262. See 42 U.S.C. § 1983 (1994); Ex parte Young, 209 U.S. 123 (1908). No such injunction was necessary in Alden, because the states had concededly come into compliance with the FLSA by the time of the lawsuit.

It appears that the FLSA, as currently written, authorizes employees to obtain such injunctions only if the state is alleged to be violating its provisions conceming retaliatory discharge. See 29 U.S.C. \$216(b) (1994) (authorizing suits by employees for "legal or cquitable relief" for violation of the prohibition of retaliatory discharge). It authorizes the Secretary of Labor to seek an injunction requiring compliance with the FLSA's other provisions, see id. $\$ 217$. and it authorizes employees to sue for money damages for violations of minimum-wage and minimum-hour provisions, see id. \$ 216(b). The FLSA's failure to authorize cmployees to obtain injunctive relief against employers who violate the minimum-wage and minimum-hour provisions may well preclude such relief against state officials under an Ex parte Young theory or under $\S 1983$. Cf. Seminole Tribe v. Florida, 517 U.S. 44. 74 (1996) (finding prospective relief unavailable under Ex pane Young if such relief would be incompatible with the statutory scheme); Middlesex County Sewerage Auth. v. National Sea Clammers Ass'n. 453 U.S. 1. 20 (1981) (finding the same under § 1983). But of. Wright v. City of Roanoke Redev. \& Hous. Auth., 479 U.S. 418, 425 (1987) (finding a strong presumption that relief under $\S 1983$ is not barred by a statute creating substantive rights). Professor Meltzer has expressed the view that Congress would have to amend the FLSA to authorize employees to obtain injunetive relief against officials. See Meltzer, supra note 3 . If the only reason the employees in Alden lacked a property interest in their accrued wages (and hence a right to compensatory relief) was, ironically, that the statute entitled them only to backpay, cf. supra note 210 (citing authority for the proposition that properny exists if the rightholder may seek specific performance). Congress could easily fix the problem by authorizing injunctive relief. But of. College Sav. Bank, 119 S. Ct. at 2225 (finding that the petitioner lacked a property interest even though the relevant statute entided it to injunctive relief). 
the state even if sovereign immunity would otherwise protect the state from damage suits.

Do employees who are legally entitled to be paid a minimum wage have a property interest in their past-due wages separate from the cause of action Congress purported to give them? If the answer is no, it is driven by the demands of the sovereign immunity doctrine, not by any coherent understanding of the concept of property. The employees clearly had a substantive right to the wages. As noted, state sovereign immunity would not bar a suit for prospective relief under Ex parte Young or $\S 1983$ (unless Congress is deemed to have forbidden it). ${ }^{263}$ Yet prospective relief would necessarily rest on the proposition that they had a right to be paid such wages in the future when and if they performed the work. ${ }^{264}$ It seems incoherent to say that before earning the wages, the employees had a conditional right to be paid such wages, but, having satisfied the condition, they now have no right to the wages.

Admittedly, the employees' right to prospective relief does not show that the employees had a property right in their accrued wages. Section 1983 authorizes prospective relief to enforce federal rights even if they are not property rights. It would be consistent with the availability of prospective relief to say that a right to money is not a property right unless it is accompanied by a right to maintain an action against the employer in court. If so, the employees would lack a property right in their accrued wages because sovereign immunity denies them a cause of action. But this conclusion would be inconsistent with Florida Prepaid and other cases in which a property right was found to have been created against a state by federal legislation enacted under Article ${ }^{265}{ }^{265}$ In the light of Seminole Tribe and Alden, all such cases establish that the existence of a property right against the state does not turn on the putative property holder's capacity to enforce the right against the state in court. Alden's right to accrued wages is distinguishable from conceded property rights, such as causes of action, solely on the ground that, because of sovereign immunity, he lacked the capacity to maintain an action in court for money damages after the right

263. Any such conclusion would be questionable. At any rate, Congress can easily fix that problem if doing so were necessary to entitle employees to compensatory relief against the state on a due process theory.

264. Prospective relief would be available only if the plaintiff could show that the act or omission threatened by the defendant, if carried out, would infringe the plaintiff's federal rights.

265. See, e.g., Mathews v. Eldridge, 424 U.S. 319 (1976); Goldberg v. Kelly, 397 U.S. 254 (1970). This standard also seems inconsistent with the cases holding that the Due Process Clause is itself sometimes the source of a remedial obligation, and with the decisions establishing that the contours of a property right, and thus of a state's procedural obligations under the Due Process Clause, are not subject to the procedural limits the state has established in creating the right. See Cleveland Bd. of Educ. v. Loudermill, 470 U.S. 532 (1985) (rejecting Justice Rehnquist's "bitter with the sweet" doctrine). 
had accrued. If such capacity is not a sine qua non of property, it seems to follow that Alden's right to accrued wages is property.

The conclusion that state employees lack a property right in their accrued wages once they have earned them conflicts even more clearly with the "new property" cases. In those cases, persons who had been receiving benefits in the past obtained an injunction in the federal courts prohibiting the state from failing to pay them benefits due in the future without first holding a hearing to establish their ineligibility for the benefits. In upholding that relief, the Court concluded that the plaintiffs had a property interest in their benefits. Analytically, benefits seem indistinguishable from accrued wages: They are both statutorily grounded rights to receive money from the state. If the former is a property right, then it seems difficult to deny that status to the latter. ${ }^{266}$ Although the benefits at issue in Goldberg were unaccrued, Alden need not claim that unaccrued benefits are property. The plaintiffs in Goldberg would have been entitled to prospective relief only if they could show that a violation of their federal rights was threatened. The federal right at issue was the right to due process, a right that exists only with respect to "property" and "liberty." 267 The plaintiffs in these cases thus had to show not only that they had a right to receive benefits once the benefits accrued, but also that what they were claiming they were eligible for would, once accrued, be a property right. ${ }^{268}$ The "new property" cases thus establish that someone who has an accrued right to money from the state has a property right, notwithstanding the state's sovereign immunity. If so, then the Due Process Clause, as construed in Florida Prepaid, required the state to afford an adequate remedy to the plaintiffs in Alden. ${ }^{269}$

266. I doubt that the Court would seek to distinguish the right to benefits from the right to wages because of the former's importance, or on some similar ground. College Savings Bank purports to rest on notions about the essence of a property right. If this essence tums on history or tradition, the most plausible basis for distinguishing between the two would be the longdiscredited distinction between rights and privileges. A resurrection of that distinction, however, would lead the Court to conclude that accrued wages are property, but that welfare benefits or continued government employment is not.

267. The benefits in Goldberg and Mathews had their sourees in both federal and state law, but the plaintiffs were suing to enforce their constitutional due process rights. The Court would presumably have decided those cases the same way had the benefits been entirely crearures of state law. See American Mfrs. Mut. Ins. Co. v. Sullivan, 119 S. Ct. 977,982 (1999) (considering a due process claim in the context of state-created benefits and distinguishing Goldberg and Mathews on other grounds). Where the benefits are creatures of statc law, the only conceivable basis for federal-court relief under $\S 1983$ would be the due process claim. which turns on the conclusion that a right to the benefits, once accrued, is a property right.

268. Because they were litigating about the timing of the right to a hearing conceming eligibility, the Goldberg plaintiffs did not in fact have to show that they would have been eligible for the benefits in the future, but the resolution of the case does rest on the conclusion that what they were claiming they were eligible for is a property right once accrued.

269. As discussed in Part II, the Coun in Florida Prepaid made it clear that a state "deprives" persons of property only when it acts willfully. See supra text accompanying note 108. As discussed above, this may mean that a deprivation does not occur if the federal law that 
American Manufacturers suggests that the Court might distinguish the right involved in Goldberg from the right involved in Alden on the ground that the right of the welfare recipient to benefits had already been established by an administrative agency or court, while the employees' right to the wages had not been. As noted above, even without an administrative or judicial decree, an employee would have a property right against a private employer who failed to pay accrued wages. But that property right takes the form of a cause of action, and a state employee lacks a cause of action because the state is immune. Perhaps the Court would say that employees or welfare recipients have a property right in wages or benefits once they accrue only if they also have an administrative or judicial decree establishing their right, but otherwise they have, at best, merely a cause of action. If the entity that owes the benefits or wages is immune, however, there would be no cause of action and thus no property right.

Again, this standard would accommodate the sovereign immunity cases, but only by molding the definition of property around them. Yet this standard too would conflict with the cases. A patent might be property under this test because the process of procuring a patent includes the issuance of a document by an administrative agency (a sort of administrative "establishment" of the right). But trademark rights based on the common law, or rights under federal law based on an unregistered copyright, would appear not to be protected. This conflicts with the suggestion in College Savings Bank that trademarks and copyrights are property, as well as with cases finding that trade secrets are property. ${ }^{270}$ Indeed, the Court's concession that goodwill is property contradicts the claim that prior adjudication is a necessary element of a property right. ${ }^{271}$ American Manufacturers recognizes that someone whose eligibility for past installments has been judicially or administratively established is entitled to be paid future installments even if he is substantively ineligible for them unless his ineligibility has been established through specified procedures. It does not hold or even imply that someone who claims to be owed money

the state violated was not "clearly established." See supra text accompanying notes 124-127. If so, then the plaintiffs in Alden might have lost their Due Process claim on that ground, as the state apparently disputed its legal obligation on the facts. See Alden v. Maine, 119 S. Ct. 2240. 2269 (1999) (describing the parties' respective positions when the suit was commenced as "an initial good-faith disagreement about the requirements of the FLSA"). But cf. supra text accompanying notes 124-127 (discussing whether a due process right to compensation for deprivation of property is subject to an exception for deprivations that violate not-clearly-established law).

270. See, e.g., Ruckelshaus v. Monsanto Co., 467 U.S. 986, 1002-04 (1984).

271. The Court could, I suppose, hold that prior judicial or administrative "establishment" of eligibility is necessary only if the claimed property right is a right to money from the state, but this would make it entirely transparent that the sovereign immunity tail is wagging the due process dog. 
for work already performed lacks a property right until after his right to the money has been established.

In sum, the new property cases appear to require the conclusion that the right to accrued wages involved in Alden was a property right within the meaning of the Due Process Clause, and that the state was thus required by that clause to afford an adequate remedy in its own courts. If accrued wages and goodwill are property rights, however, then Alden's holding that states need not entertain suits against themselves in their own courts would mean very little. If accrued wages are property, then so, it seems, would be any unliquidated debt. Louisiana would accordingly have been required by the Due Process Clause to provide a remedy against itself for deprivation of its debt to Hans. Similarly, the retrospective monetary relief found unavailable in federal court in Edelman v. Jordan ${ }^{272}$ and like cases would be available, as a matter of due process, in the state courts. If goodwill is property, then the Due Process Clause would appear to require a remedy for any injury (or at least any economic injury) resulting from the state's violation of a federal statute establishing a right of action for compensatory relief. ${ }^{273}$ If so, Alden would be reduced to holding that states cannot be sued without their consent for negligent conduct or for noncompensatory relief. This would accord with the idea, supported by past decisions, that the Due Process Clause protects "all the interests in personal security... which had been protected from private interference by the common-law courts." 274 But the Court in Alden left no doubt that it believed Louisiana was perfectly free to deny Hans a remedy against itself in its courts. ${ }^{275}$ And the Court in College Savings Bank appeared to reject the idea that the Due Process Clause protects all interests protected by the common law when it quoted Paul $v$. Davis's dictum that the Due Process Clause is not a "font of tort law." 276

If the Court's definition of property in College Savings Bank was driven by a perceived need to keep the Due Process Clause from becoming a font of tort law and thus gutting its recent sovereign immunity holdings, then the Court's project will require it to narrow as well the definition of liberty. ${ }^{277}$ Until recently, the Court basically applied the same test for the two concepts, a test that turned on whether the law placed mandatory

272. 415 U.S. 651 (1974).

273. Indeed, the Due Process Clause would require a remedy even if Congress did not create a right to compensatory relief.

274. Monaghan, supra note 166, at 423 (citing Busler v. Perny. 240 U.S. 328 (1916), for the proposition that the concept of "liberty" embraces all such rights).

275. See Alden v. Maine, 119 S. Cl. 2240, 2262-63 (1999).

276. College Sav. Bank v. Florida Prepaid Postsecondary Educ. Expense Bd., $119 \mathrm{~S}$. $\mathrm{Ct}$. 2219, 2225 (1999) (quoting Paul v. Davis, 424 U.S. 693, 701 (1976)).

277. Cf. Terrell, supra note 181, at 513 (proposing a narrow definition of "property" but a broad definition of "liberty" that would include "any ... right relating to use of the court system"). 
limitations on the state's discretion. ${ }^{278}$ In Sandin v. Conner, the Court selfconsciously departed from this approach with respect to the putative liberty interests of prisoners, but it indicated that the prior approach "may be entirely sensible" with respect to "the rights and remedies available to the general public." ${ }^{279}$ Salvaging the Court's sovereign immunity holdings, however, will require a narrowing of liberty for the general public as well.

The Court's approach to defining "liberty" in Sandin, like its approach to "property" in Goldberg and similar cases, was avowedly functional: The Court took account of "due process" interests in the context of prison litigation and defined liberty to advance them. In College Savings Bank, by contrast, the Court purported to look (albeit vainly) for the essence of the idea of property. If the Court in fact narrowed the definition of property in order to salvage its sovereign immunity precedents, however, its approach was in the end just as instrumental as that in Goldberg and Sandin. But there would be an important difference (besides lack of candor): The latter cases defined property and liberty to advance the goals of the Due Process Clause, a clause whose presence in the Constitution is a testament to our commitment to the rule of law. College Savings Bank, on the other hand, may have defined these concepts in such a way as to accommodate the Court's holdings affirming a doctrine that is widely regarded as conflicting with the ideal of the rule of law-and, indeed, is closely associated with "legal irresponsibility." ${ }^{280}$ The latter doctrine has been defended largely on historical grounds, most persuasively on grounds of stare decisis. ${ }^{281}$ Functional defenses of the doctrine of sovereign immunity have been typically confined to the claim that its effects are not so pernicious as to justify a departure from precedent. ${ }^{282}$ College Savings Bank, however, suggests that the doctrine is beginning to produce quite pernicious effects well beyond the usual sphere of its application.

\section{CONCLUSION}

It seems unlikely that the Court in Alden intended to articulate a principle that it understood was being substantially undone on the same day by the due process principle articulated in Florida Prepaid. Some of the Court's language in College Savings Bank, when considered alongside Alden, suggests strongly that the Court means to maintain a robust sovereign immunity doctrine by narrowing significantly the definition of the "property" protected by the due process principle. The many doctrinal

278. See Sandin v. Conner, 515 U.S. $472,479-80$ (1995).

279. Id. at 481 .

280. Keifer \& Keifer v. Reconstruction Fin. Corp., 306 U.S. 381,388 (1939).

281. See generally Vázquez, supra note 11 , at 86-88.

282. See id. at 87. 
conundrums posed but not directly addressed by the opinions, however, indicate that, while the Court may intend to move in this direction, it has not completely worked through the implications of its holdings.

Anticipating Alden three years ago, I suggested in the pages of this journal that narrowing the definition of property and liberty would be a bad way to address the doctrinal problems that the decision would pose. ${ }^{233}$ Due process is essential to the rule of law. To narrow the scope of the Due Process Clause to accommodate sovereign immunity only compounds the rule-of-law problems traceable to a doctrine that is already highly suspect from a rule-of-law perspective. I suggested an alternative solution to the doctrinal problems: Interpret the Due Process Clause as protecting a broad range of property and liberty interests and as requiring a hearing (although not necessarily a predeprivation hearing) and fair procedures, but not a remedy against the state itself. The constitutionally required remedy, I suggested, is one against state officials who violate federal law. ${ }^{284}$ Because sovereign immunity, under current doctrine, does not bar suits against state officials, an officer-liability regime of constitutional remedies need not be designed around the Eleventh Amendment or state sovereign immunity.

An alternative solution to these doctrinal problems would be to abandon the doctrine of sovereign immunity recognized in such cases as Seminole Tribe and Alden. In my previous article, I suggested that as long as officers remain answerable for the states' violations of federal law, the doctrine of sovereign immunity, as eventually recognized in Alden, would be tolerable from a rule-of-law perspective. ${ }^{285}$ The Court's more recent cases, however, require two qualifications. First, the Court's recent decisions may signal a contraction of the basic procedural protections guaranteed by the Due Process Clause. ${ }^{286}$ Second, the Court's sovereign immunity and due process decisions have produced a doctrinal maze that, with every new case, becomes more bewildering in its complexity. Doctrinal complexity is problematic from a rule-of-law perspective. A principal point of law is to guide human conduct, and, to this end, a measure of certainty and predictability in the law is essential. Constitutional doctrine that can be understood, if at all, only with the sorts of conceptual pirouettes attempted in Part III of this Essay cannot hope to provide meaningful guidance to litigants or lower courts, or even to the Court itself, let alone to ordinary citizens. That is unacceptable from a rule-of-law perspective.

283. See Vázquez, supra note 14, at 1751-53.

284. See id at $1770-85$.

285. See id. at 1790-804.

286. The recent decisions may also signal a contraction of remedies available against state officials. See, e.g., Idaho v. Coeur d'Alene Tribe, 521 U.S. 261 (1997), discussed in Vazquez. supra note 11 , at 42-51, 83-94. If so, then denying remedies against the state itself is more problematic. See id. 
